\title{
The potential of anti-malarial compounds derived from African medicinal plants, part II: a pharmacological evaluation of non-alkaloids and non-terpenoids
}

\author{
Fidele Ntie-Kang ${ }^{1,2+}{ }^{1}$ Pascal Amoa Onguéné ${ }^{3 \dagger}$, Lydia L Lifongo ${ }^{1}$, Jean Claude Ndom³ ${ }^{3}$. Wolfgang Sippl ${ }^{2}$
} and Luc Meva'a Mbaze 3* $^{*}$

\begin{abstract}
Malaria is currently a public health concern in many countries in the world due to various factors which are not yet under check. Drug discovery projects targeting malaria often resort to natural sources in the search for lead compounds. A survey of the literature has led to a summary of the major findings regarding plant-derived compounds from African flora, which have shown anti-malarial/antiplasmodial activities, tested by in vitro and in vivo assays. Considerations have been given to compounds with activities ranging from "very active" to "weakly active", leading to $>500$ chemical structures, mainly alkaloids, terpenoids, flavonoids, coumarins, phenolics, polyacetylenes, xanthones, quinones, steroids and lignans. However, only the compounds that showed anti-malarial activity, from "very active" to "moderately active", are discussed in this review.
\end{abstract}

Keywords: Africa, Malaria, Medicinal plants, Natural products, Traditional medicine

\section{Background}

Malaria is caused by protozoans of the genus Plasmodium (Plasmodium falciparum, Plasmodium malariae, Plasmodium ovale, and Plasmodium vivax) [1,2]. According to the World Health Organization (WHO), about half of the world's population is at risk of malaria and one to two million annual deaths (mostly among African children) can be attributed to malaria alone [3,4]. The causative agent is transmitted by the female Anopheles mosquito species, which has also developed resistance against insecticides, such as dichlorodiphenyltrichloroethane (DDT), and chemoprophylaxis has not often yielded the expected results [2]. Additionally, the diseasecausing protozoans have developed resistance against most of the drugs currently used to treat malaria. There is an urgent need to discover new active compounds.

\footnotetext{
* Correspondence: Imbazze@yahoo.fr

${ }^{\dagger}$ Equal contributors

${ }^{3}$ Department of Chemistry, Faculty of Science, University of Douala, PO Box 24157, Douala, Cameroon

Full list of author information is available at the end of the article
}

Nature, and particularly plants are a potential source of new anti-malarial drugs, since they contain a quantity of metabolites with a great variety of structures and pharmacological activities. Traditional preparations (with the use of macerations, extracts, steam baths, concoctions, and decoctions from plant materials) have been the main source of treatment of malaria in Africa [5] and other continents where the disease is endemic [6,7]. Thus, with failing treatment regimens, many research groups in Africa (African indigenous research groups and their foreign collaborators) have resorted to plant sources in the quest to expand the anti-malarial chemotherapeutic arsenal $[1,8,9]$. This effort has been motivated by the use of these plant materials in the treatment of malaria and fevers in African traditional medicine (ATM). The results from Africa and other continents have been quite promising and hence there has been a general call for the use of natural products as drugs or as sources of inspiration for the development of novel anti-malarials, in order to possibly avoid problems related to drug resistance [10-12]. 
It is believed that the next generation anti-malarials or the scaffolds necessary for their synthesis may be found in the plants currently used in ATM $[13,14]$. However, the last review on anti-malarial compounds from African flora dates back about ten years [13], with other reviews focusing on plant-screening campaigns in particular regions and/or countries in Africa [15-35] or on active compounds obtained by bioassay-guided fractionation efforts from given countries and/or regions, not covering an entire continent [36-41]. Even though natural products that are active against $P$. falciparum have been discussed in a number of review papers [1,42-48], the goal has been to provide an coverage of the most promising anti-malarials from the entire African continent, by giving an overview of the most pertinent in vitro and in vivo screening results reported in the literature. The most successful anti-malarials in use to date have been derived from natural product sources (quinolones/artemisinins). It is indeed a glaring omission that the African continent, despite its rich ethno-pharmocological heritage, is yet to yield a significant contribution in this respect. Clearly, as a first step, a systematic review of the many traditional therapeutic options is needed and this review addresses an important issue in this aspect. In part I, the most promising alkaloids and terpenoids were presented [49], while in this part the most interesting findings for flavonoids, coumarins, phenolics, polyacetylates, xanthones, quinones, steroids, and lignans are shown. The last part of the work is essentially focused on the cheminformatic analysis of $>500$ natural products (NPs), derived from African medicinal plants, which have demonstrated from weak to very good in vitro anti-malarial activities, with a focus on molecular descriptors related to "drug-likeness", drug metabolism and pharmacokinetics (DMPK). The predicted properties of plant-derived anti-malarials are those related to drug absorption, distribution, metabolism, elimination, and toxicity (ADMET) based on in silico computed molecular descriptors.

\section{Promising anti-malarial agents derived from African flora}

By convention, activities were categorised into "very potent", "good", "good to moderate", "weak", "very weak" and "inactive". Following criteria used by Mahmoudi et al. [50] and Wilcox et al. [51], a pure compound was considered highly active if $\mathrm{IC}_{50}<0.06 \mu \mathrm{M}$, being active with $0.06 \mu \mathrm{M} \leq \mathrm{IC}_{50} \leq 5 \mu \mathrm{M}$, weakly active when $5 \mu \mathrm{M} \leq$ $\mathrm{IC}_{50} \leq 10 \mu \mathrm{M}$ and compounds with $\mathrm{IC}_{50}>10 \mu \mathrm{M}$ were considered inactive. The following inhibition percentages were proposed for in vivo activity of antimalarial extracts at a fixed dose of $250 \mathrm{mg} \mathrm{kg}^{-1}$ day $^{-1}$ : 100-90\% (very good activity); $90-50 \%$ (good to moderate); $50-10 \%$ (moderate to weak); 0\% (inactive) [52].

\section{Flavonoids}

Several bioactive flavonoids have been derived from medicinal plants growing in Africa. Even though the molecular mechanism of action of anti-malarial activities of flavonoids is not fully elucidated, it is believed that flavonoids act by inhibiting the fatty acid biosynthesis (FAS II) of the parasite [53,54]. Some flavonoids have also been shown to inhibit the influx of $L$-glutamine and myoinositol into infected erythrocytes [55]. The active anti-malarial flavonoids are summarized in Table 1, while the chemical structures are shown in Figures 1, 2 and 3 .

\section{Chalcones}

Several anti-malarial flavonoids have been isolated from the stem bark of Erythrina abyssinica by Yenesew et al. $[56,57]$. These include chalcones, prenylated and nonprenylated isoflavones and flavones, pterocarpenes, and flavenes. All compounds exhibited moderate anti-malarial activity against the D6 and W2 strains of P. falciparum. The ethyl acetate extract of the stem bark of this plant showed anti-plasmodial activity against the chloroquinesensitive (D6) and chloroquine-resistant (W2) strains of P. falciparum with $\mathrm{IC}_{50}$ values of 7.9 and $5.3 \mu \mathrm{g} \mathrm{mL} \mathrm{m}^{-1}$, respectively. From this extract, a new chalcone, $2^{\prime}, 3,4,4^{\prime}$ tetrahydroxy-5-prenylchalcone or 5-prenylbutein (1), a new flavanone, 4',7-dihydroxy-3' -methoxy-5' -prenylflavanone (trivial name, 5- deoxyabyssinin II) and homobutein (2), along with known flavonoids have been isolated as the antiplasmodial principles. Yenesew et al. also investigated the stem bark of Milletia usaramensis ssp. usaramensis (Leguminosae) from Kenya [58]. The chalcone 4'-O-geranylisoquiritigenin (3) was isolated. This compound exhibited moderate to weak antiplasmodial activity against the D6 and W2 strains of P. falciparum. Nkunya et al. investigated several Tanzanian species of the genus Uvaria [59]. Petroleum ether, dichloromethane and methanol extracts of leaves, stem, and root bark of nine Uvaria species: Uvaria dependens, Uvaria faulknerae, Uvaria kirkii, Uvaria leptocladon, Uvaria lucida ssp. lucida, Uvaria sp. (Pande), Uvaria scheffleri, and Uvaria tanzaniae were tested for their in vitro activity against the multidrugresistant $\mathrm{K}-\mathrm{l}$ strain of $P$. falciparum. The $\mathrm{IC}_{50}$ values of the extracts varied between 5 and $500 \mu \mathrm{g} \mathrm{mL}^{-1}$. The most active extracts were obtained from the stem and root bark of $U$. lucida ssp. lucida and Uvaria sp. (Pande) and the root bark of $U$. scheffleri, all of which had $\mathrm{IC}_{50}$ values between 5 and $9 \mu \mathrm{g} \mathrm{mL} \mathrm{m}^{-1}$. The investigations of these authors yielded five important chalcones, uvaretin (4), diuvaretin (5), triuvaretin, isotriuvaretin and chamuvaretin (6). These compounds showed moderate to high antiplasmodial activity against the multidrug-resistant K-1 strain of $P$. falciparum, with respective $\mathrm{IC}_{50}$ values of $3.49,4.20$, 46.02, 20.85 and $5.32 \mu \mathrm{g} \mathrm{mL} \mathrm{m}^{-1}$. Joseph et al. also isolated two 
Table 1 Summary of promising anti-malarial flavonoids derived from African flora

\begin{tabular}{|c|c|c|c|c|c|}
\hline Compound subclass & Isolated metabolites & Plant species (Family) & Part of plant studied & $\begin{array}{l}\text { Place of harvest } \\
\text { (locality, country) }\end{array}$ & Author, reference \\
\hline \multirow[t]{7}{*}{ Chalcones } & 1 and 2 & Erythrina abyssinica (Leguminosae) & Stem bark & Thika town, Kenya & Yenesew et al. [56,57] \\
\hline & 3 & Milletia usaramensis ssp. usaramensis (Leguminosae) & Stem bark & Jadini Forest, Kenya & Yenesew et al. [58] \\
\hline & 4, 5 and 6 & Uvaria sp. (Annonaceae) & Leaves, stem and root bark & Tanzania & Nkunya et al. [59] \\
\hline & 7 and 8 & Friesodielsia obovata (Annonaceae) & Root bark & Tabora district, Tanzania & Joseph et al. [60] \\
\hline & $9,10,11,12,13$, and 14 & Polygonum senegalense (Polygonaceae) & Aerial parts & Nairobi, Kenya & Midowo et al. [61] \\
\hline & 4 and 15 & Uvaria puguensis (Annonaceae) & Stem bark & Pugu Forest Reserve, Tanzania & Makangara et al. [62] \\
\hline & $16,17,18$, and 19 & Dorstenia barteri (Moraceae) & Twigs & Tombel, Cameroon & Ngameni et al. [63] \\
\hline \multirow[t]{5}{*}{ Flavanones } & $20,21,22,23,24$, and 25 & Erythrina abyssinica (Leguminosae) & Stem bark & Thika town, Kenya & Yenesew et al. [56,57] \\
\hline & 26 and 27 & Derris trifoliate (Leguminosae) & Seed pods & Coast Province, Kenya & Yenesew et al. [64] \\
\hline & 28 and 29 & Polygonum senegalense (Polygonaceae) & Aerial parts & Nairobi, Kenya & Midowo et al. [61] \\
\hline & 30 & Erythrina abyssinica (Leguminosae) & Stem bark & Thika town, Kenya & Yenesew et al. [57] \\
\hline & 31 and 32 & Morus mesozygia (Moraceae) & Stem bark & Centre Province, Cameroon & Zelefack et al. [65] \\
\hline \multirow[t]{2}{*}{ Isoflavones } & 33 & Ficus mucuso (Moraceae) & Figs & Tongolo-Yaoundé, Cameroon & Bankeu et al. [66] \\
\hline & 34 & Erythrina sacleuxii (Leguminosae) & Root bark & Kenya & Andayi et al. [67] \\
\hline Retonoids & $35,36,37$ and 38 & $\begin{array}{l}\text { Milletia usaramensis ssp. } \\
\text { usaramensis (Leguminosae) }\end{array}$ & Stem bark & Jadini Forest, Kenya & Yenesew et al. [58] \\
\hline
\end{tabular}




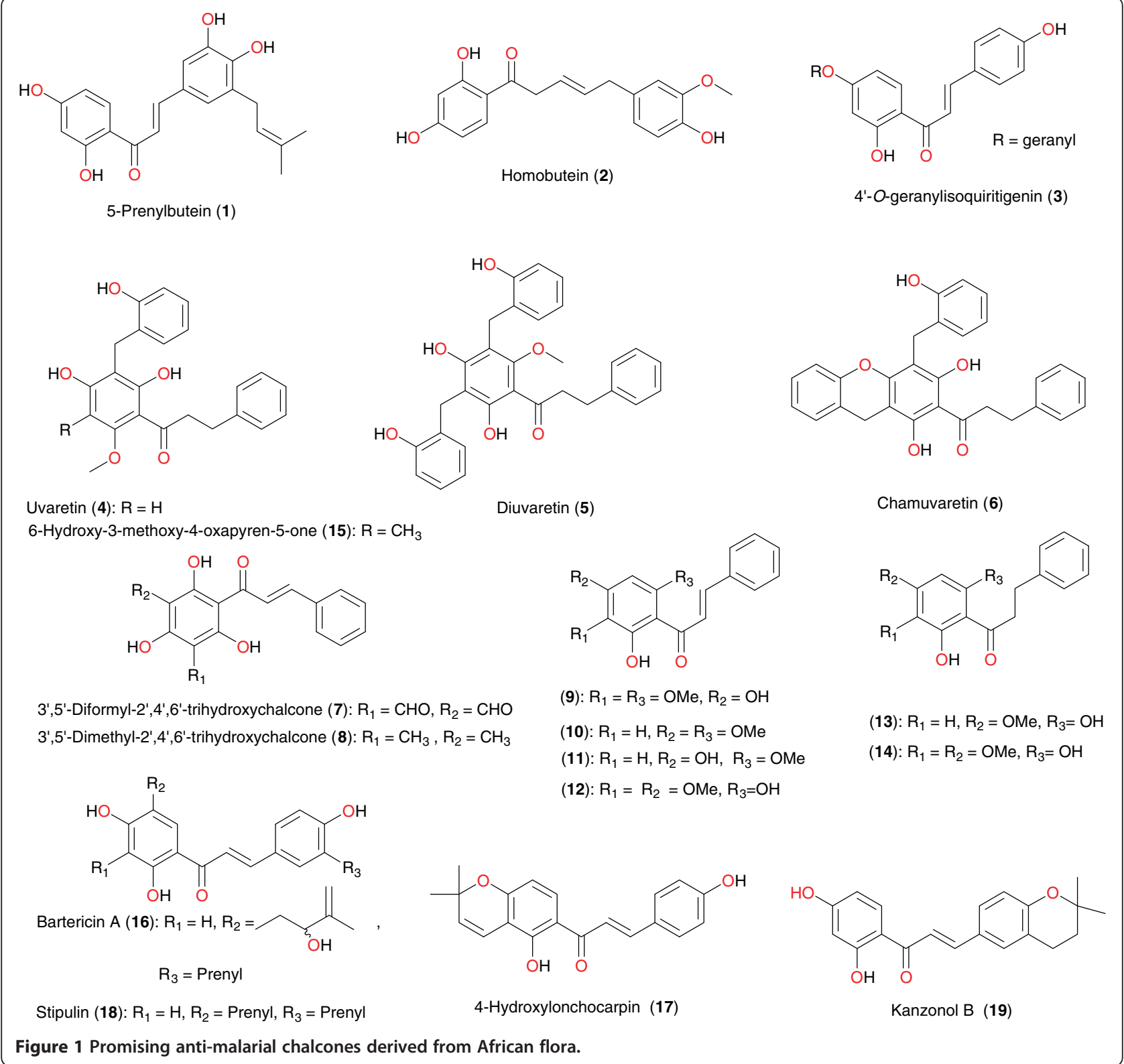

bioactive chalcones; $3^{\prime}, 5^{\prime}$-diformyl-2', $4^{\prime}, 6^{\prime}$-trihydroxychalcone (7) and $3^{\prime}, 5^{\prime}$-dimethyl-2',4',6'-trihydroxychalcone (8) from the root bark of Friesodielsia obovata [60]. These two compounds exhibited moderate antiplasmodial activity against the $\mathrm{K}-1$ strain of $P$. falciparum, with respective $\mathrm{IC}_{50}$ values of 23 and $9.7 \mu \mathrm{g} \mathrm{mL}{ }^{-1}$. The same trend of activity was observed against the NF54 strain, against which the compounds had $\mathrm{IC}_{50}$ values of 29 and $8.5 \mu \mathrm{g} \mathrm{mL} \mathrm{m}^{-1}$ respectively.

The new homoisoflavonoid, 5,7-dihydroxy-3-(hydroxyphenyl-methyl)-6-methoxy-chroman-4-one or polygohomoisoflavanone (9) was isolated from the aerial exudates of Polygonum senegalense, along with the known chalcones 10 to 14, by Midowo et al. [61]. The new compound, along with other components of the aerial exudate showed good antiplasmodial activities towards D6 and W2 strains of P. falciparum. Mukaranga et al. investigated the stem bark of Uvaria puguensis (Annonaceae) from Tanzania [62]. Repeated chromatography of the petroleum ether and chloroform extracts yielded uvaretin (4) and the new phenanthrenoid 6-hydroxy-3methoxy-4-oxapyren-5-one (15), which has been named puguenolide.

The chalcones bartericin A (16), and 4-hydroxylonchocarpin (17), stipulin (18) and kanzonol B (19) were isolated from the twigs of Dorstenia barteri (Moraceae) from Cameroon by Ngameni et al. [63]. These compounds were evaluated in culture against the W2 strain 
<smiles>COc1cc(C2CC(=O)c3ccc(O)cc3O2)cc(CC=C(C)C)c1O</smiles>

5-Deoxyabyssinin II (20)<smiles>[R]c1cc(O)cc2c1C(=O)C[C@H](c1cc(CC=C(C)C)c(O)c(CC=C(C)C)c1[R6])O2</smiles>

Abyssinone IV (21): $\mathrm{R}=\mathrm{H}, \mathrm{R}_{2}=\mathrm{H}, \mathrm{R}_{3}=$ Prenyl, $\mathrm{R}_{4}=$ Prenyl Abyssinone $\mathrm{V}(\mathbf{2 2})$ : $\mathrm{R}=\mathrm{OH}, \mathrm{R}_{2}=\mathrm{H}, \mathrm{R}_{3}=$ Prenyl, $\mathrm{R}_{4}=$ Prenyl Sigmoidin $A$ (23): $R_{1}=O H, R_{2}=$ Prenyl, $R_{3}=O H, R_{4}=$ Prenyl Sigmoidin $B(24): R_{1}=O H, R_{2}=H, R_{3}=$ Prenyl, $R_{4}=O H$<smiles>CC(C)=CCc1cc([C@H]2CC(=O)c3c(O)cc(O)cc3O2)cc2c1OC(C)(C)CC2</smiles><smiles>CC(C)=CCc1c2c(c(O)c3c1OC(c1ccc(O)cc1)CC3=O)C=CC(C)(C)O2</smiles>

(S)-Lupinifolin 4'-methyl ether (26): $\mathrm{R}=\mathrm{CH}_{3}$ Lupinifolin (27): $\mathrm{R}=\mathrm{H}$<smiles>COc1cc(C2CC(=O)c3ccc(O)cc3O2)cc(CC=C(C)C)c1O</smiles>
5-Deoxyabyssinin II (30)<smiles></smiles><smiles>COc1c(O)cc2c(c1O)C(=O)C(C(O)c1ccccc1)CO2</smiles>

9-Hydroxyhomoisoflavonoid (28) 2,3-Dihydro-5-hydroxy-7-methoxy-2-phenylchromen-4-one (29)<smiles>COc1ccc(-c2coc3cc(O)ccc3c2=O)cc1CC=C(C)C</smiles>

5-Deoxy-3'-prenylbiochanin A (34)<smiles>COc1cc(O)c2c(c1)OC(c1ccccc1)CC2=O</smiles><smiles>CC(C)=CCc1cc(-c2coc3c(C(C=C(C)C)c4cc(C5COc6cc(O)cc(O)c6C5=O)ccc4O)c(O)cc(O)c3c2=O)ccc1O</smiles>

Mucusisoflavone C (33)

Artocarpesin (31): $\mathrm{R}_{1}=\mathrm{H}, \mathrm{R}_{2}=\mathrm{OH}, \mathrm{R}_{3}=\mathrm{H}$ Kushenol E (32): $\mathrm{R}_{1}=$ Prenyl, $\mathrm{R}_{2}=\mathrm{H}, \mathrm{R}_{3}=\mathrm{OH}$

Figure 2 Flavanones and isoflavonoid with anti-plasmodial activity, derived from plants used in African traditional medicine.

of P. falciparum. The evaluated compounds were found to be active in vitro against $P$. falciparum, 16, 17 and 18, demonstrating particular potencies with relatively low $\mathrm{IC}_{50}$ values $(2.15 \mu \mathrm{M}, 3.36 \mu \mathrm{M}$ and $5.13 \mu \mathrm{M}$ respectively). The observed activities confirmed the chalcones as potential leads for the development of anti-malarials.

\section{Flavanones}

The flavanones 5-deoxyabyssinin II (20), abyssinone IV (21), abyssinone V (22), sigmoidins A (23), B (24) and E (25), as well as 5-deoxyabyssinin II (30) were isolated from the stem bark of Erythrina abyssinica (Leguminosae), harvested in Kenya [57]. The investigations of Yenesew et al. demonstrated that these compounds exhibited anti-malarial properties against the $\mathrm{W} 2$ and D6 strains of $P$. falciparum with $\mathrm{IC}_{50}$ values varying from 4.9 to $13.6 \mu \mathrm{M}$ against the latter strain and from 5.9 to $13.3 \mu \mathrm{M}$ against the former strain [56,57]. The same authors investigated the seed pods of Derris trifoliate (Leguminosae) [64]. From the dichloromethanemethanol (1:1) extract, a new flavanone derivative (S)-lupinifolin 4'-methyl ether (26) was isolated, in addition to the known flavonoids lupinifolin (27) and rotenone. Lupinfolin only showed moderate in vitro antiplasmodial activity against the D6 and W2 strains of $P$. falciparum. The different parts of this plant showed larvicidal activities against Aedes aegypti and rotenoids were identified as the active principles [64]. Midowo et al. examined the aerial exudates of Polygonum senegalense 


$$
\begin{aligned}
& \text { Usararotenoid } \mathrm{C}(35): \\
& \mathrm{R}_{1}=\mathrm{OMe}_{2} \mathrm{R}_{2}=\mathrm{Prenyl} \\
& \mathrm{R}_{1}-\mathrm{R}_{2}=-\mathrm{OCH}_{2} \mathrm{O}- \\
& (+) \text {-Usararotenoid } \mathrm{B}(37): \\
& \mathrm{R}_{1}=\mathrm{R}_{2}=\mathrm{OMe}^{2}
\end{aligned}
$$<smiles>CC1(C)CCc2c(ccc3c2O[C@H]2COc4cc5c(cc4[C@@H]2C3=O)OCO5)O1</smiles>

$(+)$-12a-epi-millettosin (38)

Figure 3 Promising anti-malarial retenoids from African medicinal plants.

and reported the isolation, characterization and antiplasmodial activities of the first 9-hydroxyhomoisoflavo noid (28), 2,3-dihydro-5-hydroxy-7-methoxy-2-phenylchromen-4-one (29), along with the antiplasmodial activities of some of chalconoids and a flavanone isolated along with it from the surface exudate of Polygonum senegalense [61].

The antiplasmodial and cytotoxic activities of flavonoids and arylbenzofuran derivatives from Morus mesozygia were investigated by Zelefack et al. [65]. This plant is used in treating many diseases, including malaria and fever. Fractionation of the methanolic extract of its stem bark led to the isolation and identification of two flavonoids: artocarpesin (31) and kushenol E (32), among other compounds (mulberrofuran F, bartericin A and 4-hydroxylonchocarpin). The methanolic extract and the isolated compounds were tested for antiplasmodial activity against the chloroquine-resistant FcB1 P. falciparum strain and cytotoxicity on MCF-7 human breast cancer cells. It was found that all compounds were active against the FcB1 strain of Plasmodium, with compounds 31, 32 and mulberrofuran $F$ exhibiting particular potency (with the median inhibitory concentrations $\mathrm{IC}_{50}=$ 2.5- $\left.2.6 \mu \mathrm{g} \mathrm{mL}^{-1}\right)$.

\section{Isoflavones}

The isoflavone dimer, mucusisoflavone $C$ (33), derived from the figs of Ficus mucuso, harvested near Yaoundé in Cameroon, exhibited a weak inhibitory activity against the validated drug target $P$. falciparum enoyl-ACP reductase (PfENR), with an $\mathrm{IC}_{50}$ value of $7.69 \mu \mathrm{M}$ [66].

The acetone extracts of the root bark and stem bark of Erythrina sacleuxii showed antiplasmodial activities against the D6 and W2 strains of P. falciparum. Further chromatographic separation of the acetone extract of the root bark by Andayi et al. afforded a new isoflavone, 7-hydroxy-4' methoxy-3'-prenylisoflavone, named 5-deoxy-3'-prenylbiochanin A (34) along with known isoflavonoids as the antiplasmodial principles [67]. Flavonoids and isoflavonoids isolated from the stem bark of E. sacleuxii were also tested and showed antiplasmodial activities.

\section{Rotenoids}

Milletia usaramensis ssp. usaramensis is a plant growing in East Africa, which is reported to contain anti-malarial flavonoids, particularly rotenoids [58]. Seven rotenoids have been reported from this species, including usararotenoid C (35), usararotenoid A (36), (+)-usararotenoid B (37), and (+)-12a-epi-millettosin (38). These compounds exhibited moderate to weak antiplasmodial activity against the D6 and W2 strains of P. falciparum. Yenesew et al. further established some structure-activity relationships. It was observed that rotenoids containing a prenyl unit or a 2,2-dimethylpyrano substituent were more potent than the non-prenylated rotenoid, e g, usararotenoid A. It was also reported that there is no significant activity for usararotenoid B, suggesting the importance of the carbonyl function at C-12 in usararotenoid A for the weak antiplasmodial activity observed.

\section{Phenolics}

Zofou et al. have isolated $p$-hydroxy-cinnamic acid (39), along with other compounds, atranorin, specicoside, $2 \beta, 3 \beta, 19 \alpha$-trihydroxy-urs-12-20-en-28-oic acid, from the stem bark of Kigelia africana (Bignoniaceae), harvested from Cameroon and performed the drug interactions of the isolated compounds among themselves, as well as their combination effects with quinine and artemether [68]. The antiplasmodial activity and drug interactions were evaluated against the multidrug-resistant W2mef 
Table 2 Summary of promising anti-malarial phenolics, polyacetylenes and quinones derived from African flora

\begin{tabular}{|c|c|c|c|c|c|}
\hline Compound class & Isolated metabolites & Plant species (Family) & Part of plant studied & Place of harvest (locality, country) & Author, reference \\
\hline \multirow[t]{8}{*}{ Phenolics } & 39 & Kigelia africana (Bignoniaceae) & Stem bark & Bandjoun, Cameroon & Zofou et al. $[68,69]$ \\
\hline & 40 and 41 & Sorindeia juglandifolia (Anacardiaceae) & Fruits & Mt. Kalla, Yaoundé, Cameroon & Boyom et al. [70] \\
\hline & & & & & Kamkumo et al. [71] \\
\hline & 42 & Combretum molle (Combretaceae ) & Stem bark & Tigray region, Northern Ethiopia & Asres et al. [72] \\
\hline & 43 & Alchornea cordifolia (Euphorbiaceae) & Leaves & Ivory Coast & Banzouzi et al. [73] \\
\hline & 44 & Vepris uguenensis (Rutaceae) & Roots & Baringo District, Kenya & Cheplogoi et al. [74] \\
\hline & 45 & Garcinia polyantha (Guttiferae) & Roots & Mt Kalla, Yaoundé, Cameroon & Lannang et al. [75] \\
\hline & 46 & Gossypium sp. (Malvaceae) & Seeds & Diverse regions from the continent & Deck et al. [76] \\
\hline Polyacetylenes & $47,48,49$ and 50 & Cussonia zimmermanii (Araliaceae) & Root bark & Pugu Forest, Tanzania & Senn et al. [77] \\
\hline \multirow[t]{8}{*}{ Quinones } & $51,52,53$ and 54 & Hoslundia opposita (Lamiaceae) & Root bark & Tanzania & Achenbach et al. [78] \\
\hline & 55 & Cassia siamea (Fabaceae) & Stem bark & Otu (Oyo State), Nigeria & Ajaiyeoba et al. [79] \\
\hline & $56,57,58,59,60$ and 61 & Psorospermum glaberrimum (Hypericaceae) & Root bark & Ekombité, Cameroon & Lenta et al. [80] \\
\hline & $62,63,64,65$ and 66 & Harungana madagascariens (Hypericaceae) & Root bark & Bazou, Cameroon & Lenta et al. [81] \\
\hline & 67 & Spathodea campanulata (Bignoniaceae) & Stem bark & Ibadan, Nigeria & Makinde et al. [82] \\
\hline & 68 and 69 & Kniphophia foliosa (Asphodelaceae) & Roots & & Dagne et al. [83] \\
\hline & & & & & Bringmann et al. [84] \\
\hline & 70 and 71 & Kigelia pinnata (Bignoniaceae) & Root bark & & Weiss et al. [85] \\
\hline
\end{tabular}




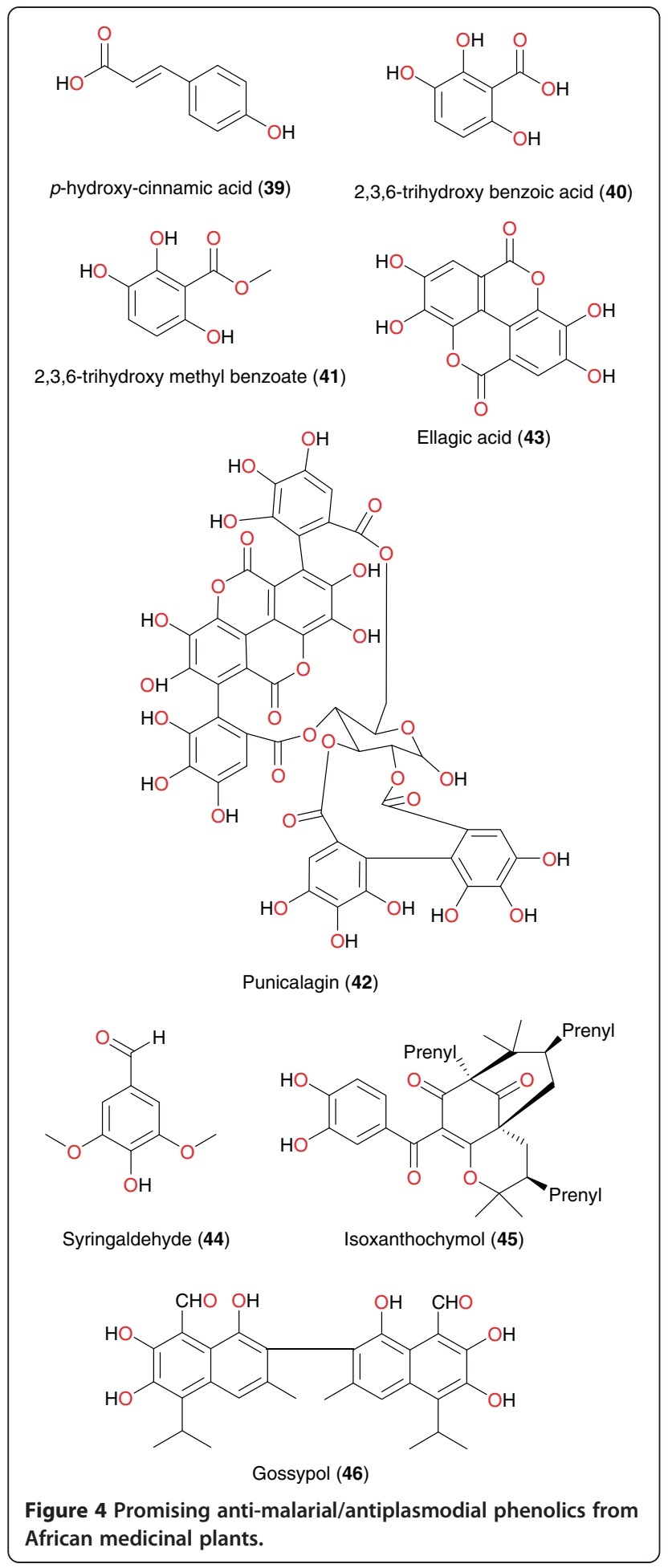

strain of $P$. falciparum. The results equally showed a slight synergistic effect between atranorin and $2 \beta, 3 \beta, 19 \alpha-$ trihydroxy-urs-12-20-en-28-oic acid (combination index, CI of 0.82) whereas the interaction between specicoside and $p$-hydroxycinnamic acid was instead antagonistic (CI of 2.67). All three compounds were shown to significantly act in synergy with some first line malaria drugs like artemether (CI of 0.42 to 0.71 ). More excitingly, none of these four compounds showed any significant sign of toxicity against the monkey kidney cell strains LLC-MK2 (selectivity index below 10). Compound 39 exhibited antiplasmodial activitity against the W2mef strain with an $\mathrm{IC}_{50}$ value of $2.11 \mu \mathrm{g} \mathrm{mL} \mathrm{m}^{-1}$ [69]. The origins of the isolated anti-malarial/antiplasmodial phenolics are shown in Table 2, while the chemical structures are shown in Figure 4.

In an effort to identify a lead compound for antimalarial drug discovery, Kamkumo et al. investigated the

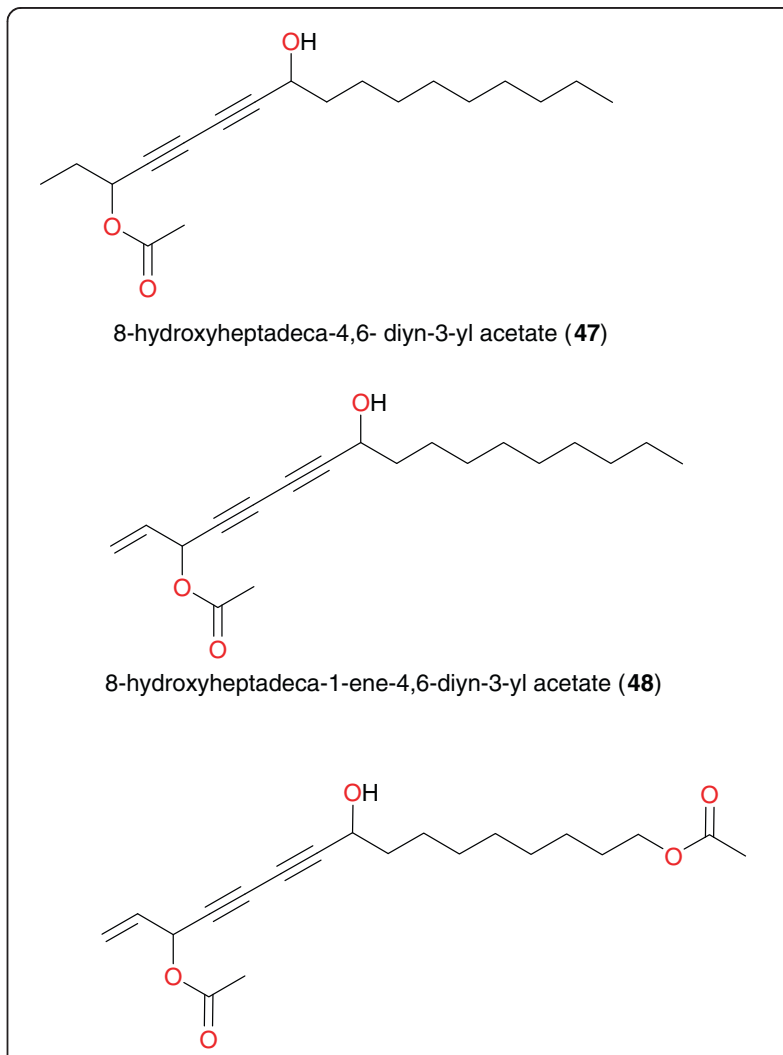

16-acetoxy-11-hydroxyoctadeca-17-ene-12,14-diynyl acetate (49)

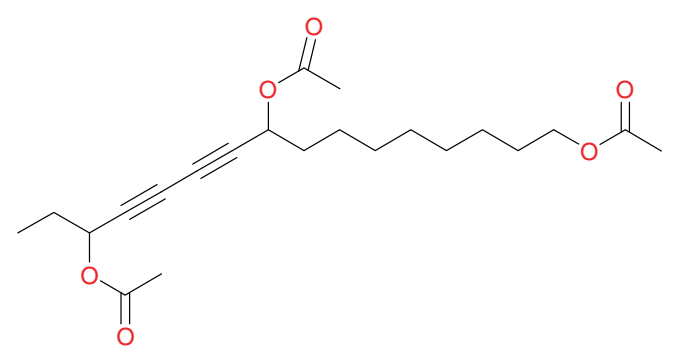

11,16-diacetoxyoctadeca-17-ene-12,14- diynyl acetate (50)

Figure 5 Some anti-malarial/antiplasmodial polyacetylenes from African medicinal plants. 
fruits of Sorindeia juglandifolia (Anacardiaceae) from Mt Kalla in Cameroon and tested the isolated compounds in vitro against the $P$. falciparum W2, against field isolates of $P$. falciparum, and against the $P$. falciparum recombinant cysteine protease falcipain-2 [70,71]. The main end products of the activity-guided fractionation were 2,3,6-trihydroxy benzoic acid (40) and 2,3,6trihydroxy methyl benzoate (41). Overall, nine fractions tested against $P$. falciparum W2 and falcipain-2 were active, with $\mathrm{IC}_{50}$ values of varying from 2.3 to $11.6 \mu \mathrm{g} \mathrm{m}^{-1}$ for W2, and 1.1-21.9 $\mu \mathrm{g} \mathrm{mL} \mathrm{m}^{-1}$ for falcipain-2. Purified compounds (40 and 41) also showed inhibitory effects against $P$. falciparum $\mathrm{W} 2\left(\mathrm{IC}_{50} \mathrm{~s} 16.5 \mu \mathrm{M}\right.$ and $\left.13.0 \mu \mathrm{M}\right)$ and falcipain-2 $\left(\mathrm{IC}_{50} \mathrm{~S} 35.4\right.$ and $\left.6.1 \mu \mathrm{M}\right)$. In studies of $P$. falciparum isolates from Cameroon, the plant fractions demonstrated $\mathrm{IC}_{50}$ values of $0.14-19.4 \mu \mathrm{g} \mathrm{mL}^{-1}$ and compounds (40 and 41) values of 6.3 and $36.1 \mu \mathrm{M}$. In vivo assessment of compound 40 showed activity against Plasmodium berghei strain B, with mean parasitaemia suppressive dose and curative dose of $44.9 \mathrm{mg} \mathrm{kg}^{-1}$ and

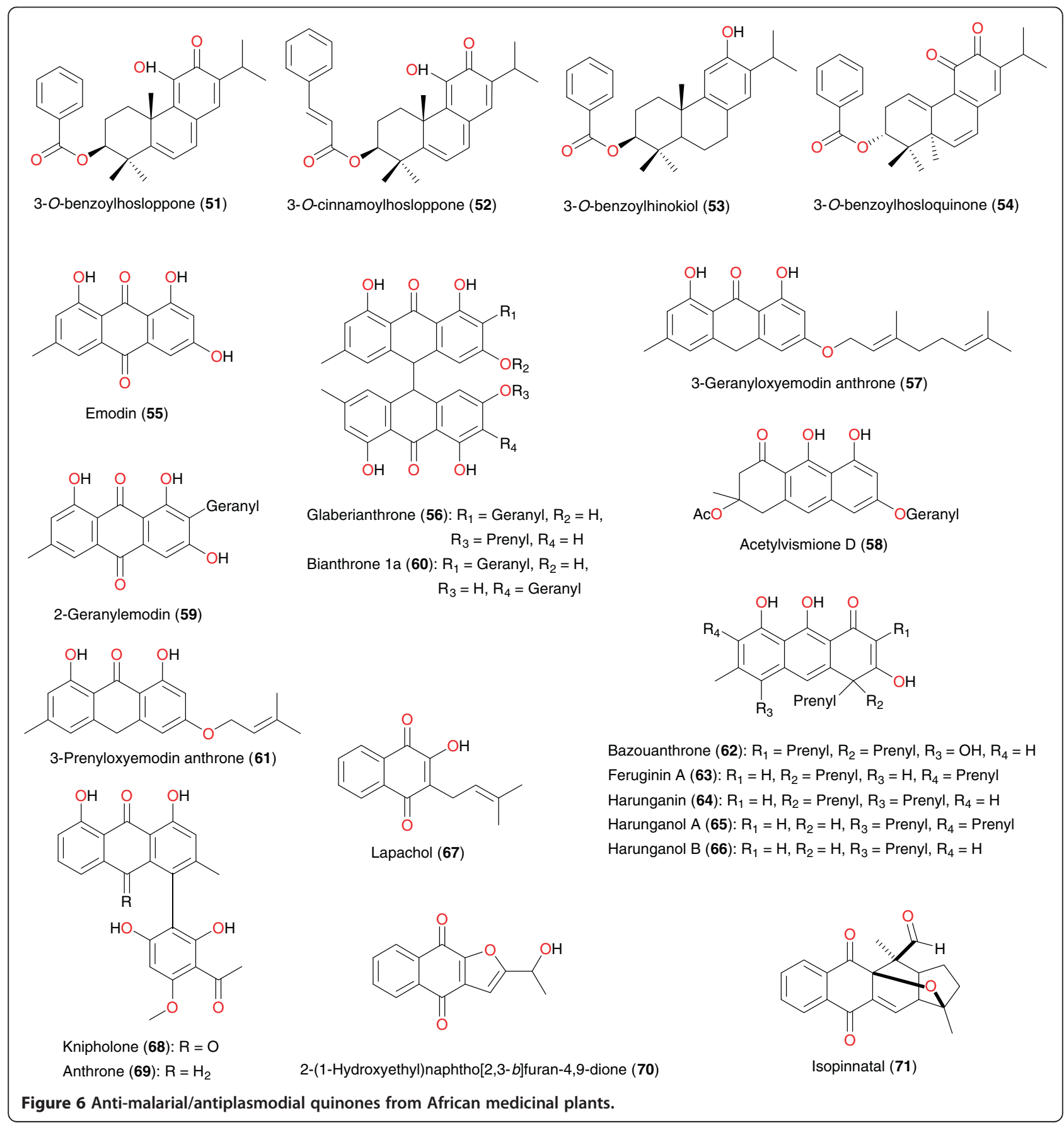


Table 3 Summary of promising anti-malarial coumarins and xanthone derived from African flora

\begin{tabular}{|c|c|c|c|c|c|}
\hline $\begin{array}{l}\text { Compound } \\
\text { class }\end{array}$ & $\begin{array}{l}\text { Isolated } \\
\text { metabolites }\end{array}$ & Plant species (Family) & $\begin{array}{l}\text { Part of plant } \\
\text { studied }\end{array}$ & $\begin{array}{l}\text { Place of harvest } \\
\text { (City, Country) }\end{array}$ & Author, Reference \\
\hline \multirow[t]{3}{*}{ Coumarins } & 72 and 73 & Vernonia brachycalyx (Asteraceae) & Roots & & Cubukcu et al. [86] \\
\hline & 74 & Toddalia asiatica (Rutaceae) & Roots & Rachuonyo District, Kenya & $\begin{array}{l}\text { Oketch-Rabah et al. } \\
\text { [88] }\end{array}$ \\
\hline & 75 & Schefflera umbellifera (Araliaceae) & Leaves & Limpopo, South Africa & Mthembu et al. [89] \\
\hline \multirow[t]{4}{*}{ Xanthones } & 76 and 77 & $\begin{array}{l}\text { Hypericum lanceolatum } \\
\text { (Hypericaceae) }\end{array}$ & Stem bark & $\begin{array}{l}\text { Mt. Bamboutos, } \\
\text { Cameroon }\end{array}$ & Zofou et al. [90] \\
\hline & $\begin{array}{l}78,79,80,81, \\
82 \text { and } 83\end{array}$ & Allanblackia monticola (Guttiferae) & Stem bark & Bagangté, Cameroon & Azebaze et al. [91] \\
\hline & 84,85 and 86 & Symphonia globulifera (Clusiaceae) & Seeds & Fundong, Cameroon & Ngouela et al. [92] \\
\hline & $\mathbf{8 7}, \mathbf{8 8 ,} 89$ and 90 & Pentadesma butyracea (Guttiferae) & Fruit pericarp & Bazou, Cameroon & Lenta et al. [93] \\
\hline
\end{tabular}

$42.2 \mathrm{mg} \mathrm{kg}^{-1}$, respectively. Active fractions were found to be safe in mice after oral administration of $7 \mathrm{~g} \mathrm{~kg}^{-1}$ body weight. These results suggest that further investigation of the anti-malarial activities of natural products from $S$. juglandifolia will be appropriate.

The Ethiopian medicinal plant Combretum molle (Combretaceae), reported to possess genuine anti-malarial activity, was investigated by Asres et al. [72]. The fractionation of the stem bark extract yielded punicalagin (42) as the active compound. This compound exhibited in vitro activity against the $3 \mathrm{D} 7$ strain of $P$. falciparum with $\mathrm{IC}_{50}$ values of $2.19 \mu \mathrm{g} \mathrm{mL}{ }^{-1}$. Ellagic acid (43), derived from the leaves of Alchornea cordifolia (Euphorbiaceae), showed good activity against $P$. berghei in mice with an $\mathrm{ED}_{50}$ in the range of 0.2-0.151 $\mu \mathrm{g} \mathrm{mL}^{-1}$ [73]. Cheplogoi et al. investigated the roots of Vepris uguenensis (Rutaceae), harvested from the Baringo District, Kenya [74]. Syringaldehyde (44) was identified as an active compound, exhibiting moderate antiplasmodial activity against two strains of $P$. falciparum, with $\mathrm{IC}_{50}$ values of $13.0 \mu \mathrm{g} \mathrm{mL} \mathrm{m}^{-1}$ (chloroquinesusceptible 3D7 strain) and $21.4 \mu \mathrm{g} \mathrm{mL} \mathrm{m}^{-1}$ (chloroquineresistant FCM29 strain), respectively.

From the methanol extract of roots of Garcinia polyantha, Lannang et al. isolated Isoxanthochymol (45), which exhibited in vitro anti-malarial activity against $P$. falciparum and showed strong chemosuppression of parasitic growth [75]. The compound exhibited antimalarial activity with an $\mathrm{IC}_{50}$ of $2.21 \mu \mathrm{M}$. This was lower than the $\mathrm{IC}_{50}$ of the other five co-occurring compounds (garcinane, smeathxanthones $\mathrm{A}$ and $\mathrm{B}$, chefouxanthone, isoxanthochymol, magnificol, and $\beta$-sitosterol and garciniaxanthone I), which ranged from 2.5 to $4.1 \mu \mathrm{M}$. The compounds were administered over a period of four days to the culture and the number of parasites was determined daily. Control experiments were performed either without treatment or with administration of $0.032 \mu \mathrm{M}$ chloroquine in the same solvent. Gossypol (46), derived from the seeds of cotton plant (Gossypium sp., Malvaceae), exhibits a variety of biological activities, including antispermatogenic, anti-cancer, antiparasitic and antiviral activity. Deck et al. demonstrated that this compound also showed antimalarial activity against both chloroquine-sensitive and chloroquine-resistant strains of $P$. falciparum, with $\mathrm{IC}_{50}$ values in the order of $10 \mu \mathrm{M}$ [76]. The presence of aldehyde functional groups renders gossypol toxic and in the light of this fact, authors further investigated synthetic analogues of compound $\mathbf{4 6}$ for biological activity. It was found that the synthetic analogues lost toxicity while retaining antiplasmodial activity.

\section{Polyacetylenes}

Polyacetylenes have unique chemical structures, which make them rare and often unstable and very reactive. They thus have a wide variety of biochemical and pharmacological uses. Senn et al. investigated the root bark extract of Cussonia zimmermanii (Araliaceae) from the Pugu Forest in Tanzania, a plant commonly used to

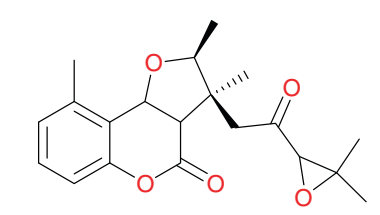

20-Epi-cycloisobrachycoumarinone epoxide (72)

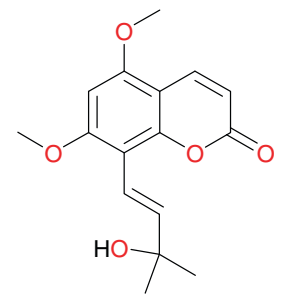

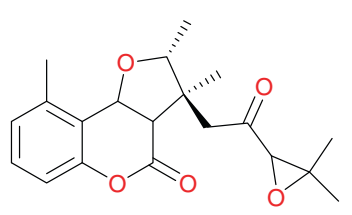

Cycloisobrachycoumarinone epoxide (73)

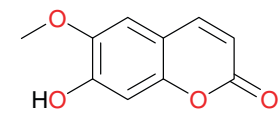

7-Hydroxy6- methoxycoumarin (75)

5,7-Dimethoxy-8-(3'-hydroxy-3'-

methyl-1'-butene)coumarin (74)

Figure 7 Coumarins from from African medicinal plants with promising anti-malarial/antiplasmodial activities. 
treat malaria, fever and epilepsy [77]. Four polyacetylenes were isolated, namely: 8-hydroxyheptadeca-4,6- diyn-3-yl acetate (47), 8-hydroxyheptadeca-1-ene-4,6-diyn-3-yl acetate (48), 16-acetoxy-11-hydroxyoctadeca-17-ene12,14-diynyl acetate (49) and 11,16-diacetoxyoctadeca17-ene-12,14-diynyl acetate (50), Figure 5. Compounds 47 to 49 showed high anti-malarial activity against $P$. falciparum, with $\mathrm{IC}_{50}$ values of $5.9,0.44$ and $0.84 \mu \mathrm{M}$ respectively.

\section{Quinones}

Quinones also exhibit diverse pharmacological properties, including anti-malarial activity. Four quinones have been isolated from the root bark of Hoslundia opposita by Achenbach et al. [78], including 3-O-benzoylhosloppone (51), 3-O-cinnamoylhosloppone (52), 3-O-benzoylhinokiol (53), and 3-O-benzoylhosloquinone (54), Figure 6. The antiplasmodial activities of compound $\mathbf{5 1}$ have helped to validate the ethnobotanical use of the plant in the<smiles>COc1ccc2c(=O)c3cccc(O)c3oc2c1</smiles>

5-Hydroxy-3-methoxyxanthone (76) 3-Hydroxy-5-methoxyxanthone (77)<smiles>CC(C)=CCc1c(O)cc2c(O)c1C(=O)C1=C(C=C(O)C(=O)C1(CC=C(C)C)CC=C(C)C)O2</smiles>

Allanxanthone C (78)<smiles>COc1c(O)cc2oc3cc4c(c(O)c3c(=O)c2c1CC=C(C)C)C=CC(C)(C)O4</smiles>

Garciniafuran (79)<smiles>COc1c(O)cc2oc3cc(O)cc(O)c3c(=O)c2c1C(=O)OCCCCC(C)(C)C</smiles><smiles>CC(C)=CCCC(C)=CCC1c2c(cc(O)c(O)c2O)Oc2cc(O)c(CC=C(C)C)c(O)c21</smiles>

Norcowanin (82)<smiles>COC1C(O)=Cc2oc3cc(O)c(CC=C(C)C)c(O)c3c(=O)c2C1CC=C(C)C</smiles>

Mangostin (83)<smiles>COc1cc2c(=O)c3c(O)c4c(c([PH2+])c3oc2c(O)c1OC)OC(C)(C)C=C4</smiles>

Gaboxanthone (84)<smiles>COc1cc2c(=O)c3c(O)c(PC4CCCCCC4)c4c(c3oc2c(O)c1OC)C=CC(C)(C)O4</smiles>

Symphonin (85)<smiles>COc1cc2c(=O)c3c(O)c([Pb])c(O)c([Pb])c3oc2c(O)c1OC</smiles>

Globuliferin (86)<smiles>COc1c(O)cc2oc3cc4oc(C(C)(C)O)cc4cc3c(=O)c2c1CC=C(C)C</smiles>

Pentadexanthone (87)<smiles>COc1c(O)cc2oc3cc(O)c(CC=C(C)C)c(O)c3c(=O)c2c1CC=C(C)C</smiles><smiles>COc1c(O)cc2oc3cc(O)c(CCC(C)(C)O)c(O)c3c(=O)c2c1CC=C(C)C</smiles><smiles>CC(C)=CCc1c(O)cc2oc3c(CC=C(C)C)c(O)c(O)c(CC=C(C)C)c3c(=O)c2c1O</smiles>

Garcinone E (90)

Figure 8 Xanthones from from African medicinal plants with promising anti-malarial/antiplasmodial activities. 
treatment of malaria [78]. The isolation of these compounds was carried out as a result of an ethnomedical use of $H$. opposita in the treatment of malaria. The $n$-hexane extract root bark gave an $\mathrm{IC}_{50}$ of $5.6 \mu \mathrm{g} \mathrm{mL}^{-1}$ and also exhibited a $26 \%$ inhibition of growth of $P$. berghei in mice, at a daily dose of $190 \mathrm{mg} \mathrm{kg}^{-1}$ body weight, for four days [78]. Only compound 51 was tested and showed significant in vitro activity against the multidrug-resistant K-1 strain and the chloroquine-sensitive NF54 strain of P. falciparum, with $\mathrm{IC}_{50}$ values of 0.4 and $0.22 \mu \mathrm{g} \mathrm{mL}^{-1}$, respectively. The other metabolites were not screened due to the limited amount available [78].

Cassia siamea (Fabaceae) was identified from southwest Nigerian ethnobotany as a remedy for febrile illness. This led to the bioassay-guided fractionation of stem bark of the plant extract, for assessing the in vitro anti-malarial activity. Emodin (55) and lupeol were isolated from the ethyl acetate fraction. Both compounds were found to be the active principles responsible for the antiplasmodial property with $\mathrm{IC}_{50}$ values of $5 \mu \mathrm{g} \mathrm{mL}$ respectively [79].

Six quinones were derived from the root bark extract of Psorospermum glaberrimum (Hypericaceae) from Cameroon by Lenta et al. [80]. These include glaberianthrone (56), 3-geranyloxyemodin anthrone (57), acetylvismione D (58), 2-geranylemodin (59), bianthrone 1a (60), and 3-prenyloxyemodin anthrone (61). The $n$ hexane extracts and the isolated compounds were tested in vitro for their antiplasmodial activity against $P$. falciparum (W2). The $n$-hexane extract showed good antiplasmodial activity, with $\mathrm{IC}_{50}$ of $0.87 \mu \mathrm{g} \mathrm{mL} \mathrm{m}^{-1}$, meanwhile 3-geranyloxyemodin anthrone and acetylvismione $\mathrm{D}$ showed the best potencies against $P$. falciparum W2 strain with $\mathrm{IC}_{50}$ of $1.68 \mu \mathrm{M}$ and $0.12 \mu \mathrm{M}$, $\left(0.66 \mu \mathrm{g} \mathrm{mL}^{-1}\right.$ and $0.054 \mu \mathrm{g} \mathrm{mL} \mathrm{m}^{-1}$ ), respectively. The same authors investigated the root bark of Harungana madagascariens (Hypericaceae), a plant whose roots and bark are used by traditional healers to treat malaria in West Province of Cameroon [81]. These authors isolated bazouanthrone (62), a new anthrone derivative, along with the known compounds, feruginin A (63), harunganin (64), harunganol A (65), and harunganol B (66). In order to validate its ethnobotanical use, the antiplasmodial activity of the isolated compounds were evaluated in culture against W2 strain of $P$. falciparum. All the compounds were found to be active against the Plasmodium parasites with bazouanthrone (62) showing particular potency $\left(\mathrm{IC}_{50}=1.80 \mu \mathrm{M}\right)$.

Makinde et al. investigated the action of extracts of the stem bark of Spathodea campanulata (Bignoniaceae) from Nigeria on Plasmodium berghei berghei in mice [82]. The blood schizontocidal activity of the extracts was studied in early and established infections using chloroquine as the reference drug. The prophylactic action of the extracts was also investigated with pyrimethamine as the standard drug. The hexane and chloroform extracts of the stem bark showed blood schizontocidal action in both the four-day test and Rane test. The chloroform extract demonstrated some prophylactic properties while the aqueous extract did not show any significant anti-malarial property. In addition, these authors were able to identify the active anti-malarial ingrediant to be lapachol (67). The other anti-malarial quinones identified were knipholone (68) and anthrone (69) from Kniphophia foliosa (Asphodelaceae) [83,84], as well as 2-(1-hydroxyethyl)naphtho[2,3-b]furan-4,9-dione (70) and isopinnatal (71) from Kigelia pinnata

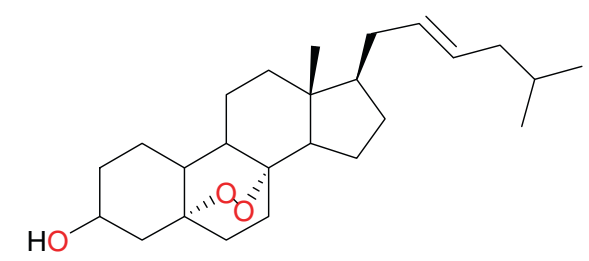

ergosterol-5,8-endoperoxide (91)

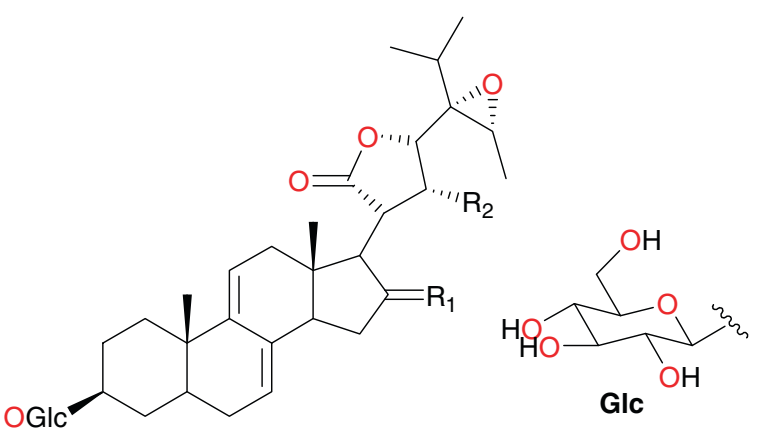

vernonioside $A 1 \mathrm{R} 1=\beta-\mathrm{OH}, \mathrm{R} 2=\mathrm{H}(\mathbf{9 2})$

vernonioside $\mathrm{A} 2 \mathrm{R} 1=\alpha-\mathrm{OH} \mathrm{P} 2=\mathrm{H}(\mathbf{9 3})$

vernonioside A3 R1 = O R2 =H (94)

vernonioside $\mathrm{B} 1 \mathrm{R} 1=\mathrm{H} \mathrm{R} 2=\mathrm{OH}$ (95)

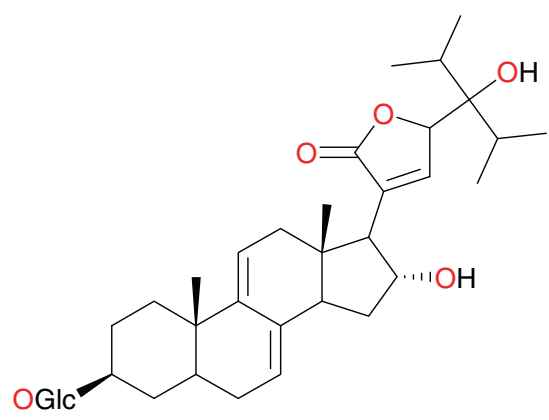

vernonioside A4 (96)

Figure 9 Steroids from African medicinal plants with antiplasmodial activity. 
Table 4 Summary of promising anti-malarial steroids, lignans, other antiplasmodial compounds derived from African flora

\begin{tabular}{|c|c|c|c|c|c|}
\hline Compound sub class & Isolated metabolites & Plant species (Family) & Part of plant studied & Place of harvest (City, Country) & Author, Reference \\
\hline \multirow[t]{2}{*}{ Steroids } & 91 & Ajuga remota (Lamiaceae) & Aerial parts & Nairobi, Kenya & Kuria et al. [94] \\
\hline & $92,93,94,95$ and 96 & Vernonia amygdalina (Asteraceae) & Young pith of trees & $\begin{array}{l}\text { Mahale Mt. National Park, } \\
\text { Tanzania }\end{array}$ & Ohigashi et al. [95] \\
\hline \multirow[t]{2}{*}{ Lignanes } & $97,98,99,100,101,102$ and 103 & Pycnanthus angolensis (Myristicaceae) & Stem bark & São Tomé and Príncipe islands & Ramalhete et al. [96] \\
\hline & 104 & Asparagus africanus (Asparagaceae) & Roots & Kenya & $\begin{array}{l}\text { Oketch-Rabah et al. } \\
\text { [97] }\end{array}$ \\
\hline \multirow[t]{11}{*}{ Others } & 105 & Lippia javanica (Verbenaceae) & Leaves and stalks & Limpopo, South Africa & Ludere et al. [98] \\
\hline & 106 & Helichrysum cymosum (Asteraceae) & Whole plant & South Africa & Jakupovic et al. [99] \\
\hline & & & & & Vuuren et al. [100] \\
\hline & $107,108,109$ and 110 & Vernonia staehelinoides (Asteraceae) & Leaves & Magaliesburg, South Africa & Pillay et al. [101] \\
\hline & 111 & Hypericum lanceolatum (Hypericaceae) & Stem bark & Mt. Bamboutos, Cameroon & Zofou et al. [90] \\
\hline & 112 & Symphonia globulifera (Clusiaceae) & Seeds & Fundong, Cameroon & Ngouela et al. [92] \\
\hline & 113 & Morus mesozygia (Moraceae) & Stem bark & Centre Province, Cameroon & Zelefack et al. [61] \\
\hline & 114 and 115 & Kigelia africana (Bignoniaceae) & Stem bark & Bandjoun, Cameroon & Zofou et al. $[64,65]$ \\
\hline & 116 and 117 & Glossocalyx brevipes (Monimiaceae) & Leaves & Kumba, Cameroon & Mbah et al. [102] \\
\hline & 118 & Asparagus africanus (Asparagaceae) & Roots & Kenya & $\begin{array}{l}\text { Oketch-Rabah et al. } \\
\text { [97] }\end{array}$ \\
\hline & 119 & $\begin{array}{l}\text { Dracaena mannii and Dracaena arborea } \\
\text { (Dracaenaceae) }\end{array}$ & Seed pulp & Nigeria & Okunji et al. [103] \\
\hline
\end{tabular}


(Bignoniaceae) [85]. These compounds were tested against chloroquine-sensitive (T9-96) and -resistant (K-1) P. falciparum strains and for cytotoxicity using KB cells. Compound $\mathbf{7 0}$ possessed good activity against both strains [ $\mathrm{IC}_{50}$ values $627 \mathrm{nM}$ (K1), $718 \mathrm{nM}$ (T9 - 96)]. Isopinnatal (71) and the co-occurring kigelinol and isokigelinol exhibited lower activity against both strains. Bringmann et al. also reported that knipholone (68) and three of its natural derivatives from the same plant, as well as seven structurally related but simplified compounds, have been examined for their antiplasmodial activity against asexual erythrocytic stages of two strains of $P$. falciparum in vitro (K1/chloroquine-resistant and NF 54/chloroquine-sensitive) [84]. All the phenylanthraquinones showed considerable activity, with only little cytotoxicity, while their anthraquinone and phenyl moieties were completely inactive.

\section{Coumarins}

Anti-malarial coumarins have been identified by Cubukcu et al. [86] and by Noster et al. [87] from Vernonia brachycalyx (Asteraceae) and Toddalia asiatica (Rutaceae), respectively. Cubukcu et al. identified two isomeric 5-methylcoumarins from the roots of V. brachycalyx; 20epi-cycloisobrachycoumarinone epoxide (72) and cycloisobrachycoumarinone epoxide (73), Table 3 and Figure 7. The results of the antiplasmodial assays against the chloroquine-susceptible 3D7 and chloroquine- resistant Dd2 strains of $P$. falciparum, showed that compound 72 was weakly active, with $\mathrm{IC}_{50}$ values of $160 \mu \mathrm{M}$ and $54 \mu \mathrm{M}$, while for compound 73 , the $\mathrm{IC}_{50}$ values were $111 \mu \mathrm{M}$ and $54 \mu \mathrm{M}$, respectively. Noster et al. also isolated compound 73 from the ether extract of Exostema caribaeum but however only moderate activity [87]. In addition, OketchRabah et al. isolated a new anti-malarial coumarin, 5,7-dimethoxy-8-(30-hydroxy-30-methyl- 10-butene) coumarin (74), from the roots of Toddalia asiatica [87]. This compound showed moderate activity against the chloroquine-sensitive K39 and chloroquine-resistant V1/S strains of $P$. falciparum strains, with $\mathrm{IC}_{50}$ values of $16.2 \mu \mathrm{g} \mathrm{mL}^{-1}$ and $8.8 \mu \mathrm{g} \mathrm{mL}^{-1}$, respectively.

The anti-malarial coumarin 7-hydroxy6-methoxycoumarin or scopoletin (75) was isolated from the dichloromethane leaf extract of Schefflera umbellifera (Araliaceae), harvested from Limpopo, South Africa by Mthembu et al. [89]. This compound was evaluated in vitro against both the chloroquine-susceptible (D10) and chloroquineresistant (K-1) strains of $P$. falciparum for anti-malarial activity, with an $\mathrm{IC}_{50}$ value of $28.2 \mu \mathrm{g} \mathrm{mL} \mathrm{m}^{-1}$.

\section{Xanthones}

The anti-malarial xanthones; 5-hydroxy-3- methoxyxanthone (76) and 3-hydroxy-5-methoxyxanthone (77) were isolated from stem bark of Hypericum lanceolatum
(Hypericaceae) from Cameroon by Zofou et al. [90], with $\mathrm{IC}_{50}$ values of $13.56 \mu \mathrm{g} \mathrm{mL} \mathrm{m}^{-1}$, and $8.28 \mu \mathrm{g} \mathrm{mL}{ }^{-1}$, respectively, on the multidrug-resistant W2mef strain of $P$. falciparum. Six other anti-malarial xanthones were isolated from the methanol extract of the stem bark of Allanblackia monticola (Guttiferae) from Cameroon, by Azebaze et al. [91]. These included allanxanthone C (78), garciniafuran (79), tovophyllin A (80), rubraxanthone (81), norcowanin (82) and mangostin (83), Figure 8. Allanxanthone $\mathrm{C}$ exhibited an $\mathrm{IC}_{50}$ of $1.3 \mu \mathrm{M}$ on $\mathrm{FcM}_{2} 9$ and an $\mathrm{IC}_{50}$ of $6.9 \mu \mathrm{M}$ on F32. The molecules with interesting activities are known to be norcowanin $\left(\mathrm{IC}_{50}\right.$ of $6.3 \mu \mathrm{M}$ on F32) and mangostin ( $\mathrm{IC}_{50}$ of $4.1 \mu \mathrm{M}$ on FcM29 and $\mathrm{IC}_{50}$ of $7.8 \mu \mathrm{M}$ on F32 [91]. More interestingly, these molecules showed no significant toxicity against the human melanoma cell A375 cell-line. The antiplasmodial activities of xanthones isolated from the seed shells of Symphonia globulifera were reported against the W2 Plasmodium sp. with respective $\mathrm{IC}_{50}$ values of $3.53,1.29$ and $3.17 \mu \mathrm{M}$, for gaboxanthone (84), symphonin (85) and globuliferin (86) [92]. Bioassay-guided fractionation of the fruit pericarp of Pentadesma butyracea, using the

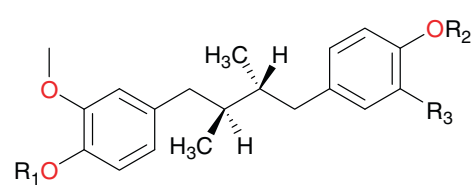

4,4'-Dihydroxy-3-methoxylignan (97): $\mathrm{R}_{1}=\mathrm{H}, \mathrm{R}_{2}=\mathrm{H}, \mathrm{R}_{3}=\mathrm{OH}$

(-)-Dihydroguaiaretic acid (98): $\mathrm{R}_{1}=\mathrm{H}, \mathrm{R}_{2}=\mathrm{H}, \mathrm{R}_{3}=\mathrm{OCH}_{3}$

4'-Hydroxy-3,3',4-trimethoxylignan (99): $\mathrm{R}_{1}=\mathrm{CH}_{3}, \mathrm{R}_{2}=\mathrm{H}, \mathrm{R}_{3}=\mathrm{OCH}_{3}$ 4,4'-Diacetyl-3,3'-dimethoxylignan (100): $\mathrm{R}_{1}=\mathrm{H}, \mathrm{R}_{2}=\mathrm{CH}_{3}, \mathrm{R}_{3}=\mathrm{OCH}_{3}$

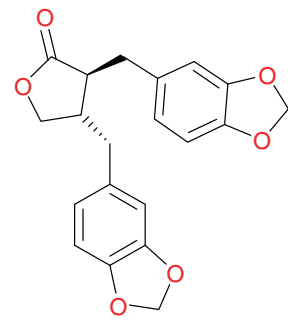

Talaumidin (101)

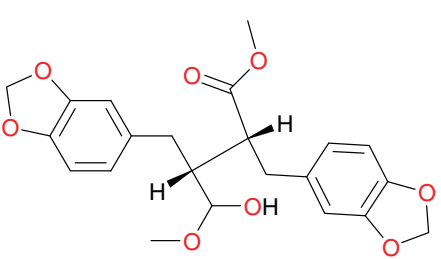

Heliobuphthalmin (103)
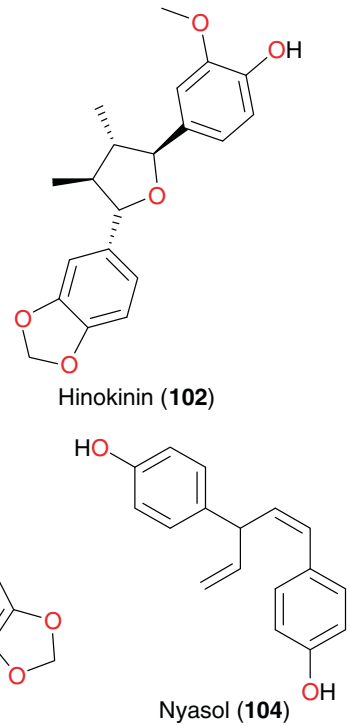

Figure 10 Lignans from African medicinal plants with promising anti-malarial/antiplasmodial activities. 
antiplasmodial test, led to the isolation of a new bioactive xanthone, named pentadexanthone (87) $\left(\mathrm{IC}_{50}=3 \mu \mathrm{M}\right.$ against W2), together with three known compounds: cratoxylone $(\mathbf{8 8})\left(\mathrm{IC}_{50}=2.89 \mu \mathrm{M}\right), \alpha$-mangostin $(89)\left(\mathrm{IC}_{50}=\right.$ $2.77 \mu \mathrm{M})$, and garcinone $\mathrm{E}(90)\left(\mathrm{IC}_{50}=0.41 \mu \mathrm{M}\right)$ [93].

\section{Steroids}

The steroid, ergosterol-5,8-endoperoxide (91), isolated from the aerial parts of Ajuga remota, exhibited high antiplasmodial activity against the chloroquine-sensitive FCA 20/GHA strain of $P$. falciparum, with an $\mathrm{IC}_{50}$ value of $8.2 \mu \mathrm{M}$ [94]. Steroidal saponins with anti-malarial activity have also been isolated from the leaves of Vernonia amygdalina [95]. Ohigashi et al. reported the isolation of vernonioside A1 (92), A2 (93), A3 (94), A4 (95) and B1 (96), Figure 9 and Table 4. These saponins had weak antiplasmodial activity against the multidrug-resistant $\mathrm{K}-1$ strain of $P$. falciparum, with $\mathrm{IC}_{50}$ values of 139.7 , 94.1, 245.1, 81.8 and $46.1 \mu \mathrm{g} \mathrm{mL}{ }^{-1}$, respectively [95]. These saponins are also reported to be the bitter compounds in the leaves of $V$. amygdalina.

\section{Lignans}

Pycnanthus angolensis (Myristicaceae) is a plant used in traditional medicine against several diseases. Its bark has been used to treat fever and malaria in São Tomé and Príncipe islands. Ramalhete et al. submitted the dichloromethane extract of the bark to anti-malarial screening and observed an activity against 3D7 P. falciparum strain $\left(\mathrm{IC}_{50}=1.6 \mu \mathrm{g} \mathrm{mL}{ }^{-1}\right)$ [96]. This was further subjected to chromatographic bioguided fractionation, yielding the lignans 4,4'-dihydroxy-3-methoxylignan (97), (-)-dihydroguaiaretic acid (98), 4' -hydroxy-3,3',4-trimethoxylignan (99), 4,4'-diacetyl-3,3'-dimethoxylignan (100), talaumidin (101), hinokinin (102), and heliobuphthalmin (103), Figure 10, along with the labdane diterpene ozic acid and the steroids stigmast-4-en-6 $\beta$-ol3 -one, stigmasterol and $\beta$-sitosterol. Furthermore, other compounds were obtained by derivatization. The in vitro anti-malarial activity of the compounds was evaluated against 3D7 and Dd2 P. falciparum strains. The best in vitro activities were exhibited by compound 97 against the 3D7 strain $\left(\mathrm{IC}_{50}=31.0 \mu \mathrm{g} \mathrm{mL}{ }^{-1}\right)$ and by compound 101 against the $\mathrm{Dd} 2$ strain $\left(\mathrm{IC}_{50}=20.7 \mu \mathrm{g} \mathrm{mL}{ }^{-1}\right)$.

Asparagus africanus (Asparagaceae) is used by the Akamba tribe in Kenya to treat malaria. A bioassayguided fractionation of the root extract led to the isolation of the lignan nyasol (104), along with the sapogenin muzanzagenin (119), Figure 11, as the bioactive compounds responsible for the anti-malarial activity of this plant [97]. Nyasol moderately inhibited P. falciparum schizonts with the $\mathrm{IC}_{50}$ of $49 \mu \mathrm{M}$, while muzanzagenin showed a moderate in vitro activity against four different malaria schizont strains the $\mathrm{IC}_{50}$ values were $16,163,23$, and $16 \mu \mathrm{M}$, respectively.

\section{Others}

Lippialactone (105), derived from the ethyl acetate extract of aerial parts of Lippia javanicais, harvested from South Africa, was shown to be active against the chloroquinesensitive D10 strain of P. falciparum with an $\mathrm{IC}_{50}$ value of $9.1 \mu \mathrm{g} \mathrm{mL}{ }^{-1}$, and is also mildly cytotoxic [98]. Helihumulone (106) was derived from extracts of the whole plant of Helichrysum cymosum (Asteraceae) from South Africa by Jakupovic et al. [99] and Vuuren et al. [100].

The dichloromethane extract of the leaves of Vernonia staehelinoides (Asteraceae) showed in vitro activity $\left(\mathrm{IC}_{50}\right.$ $\sim 3 \mu \mathrm{g} \mathrm{mL}{ }^{-1}$ ) against the chloroquine-sensitive D10 and the chloroquine-resistant (K-1) strains of $P$. falciparum [101]. Pillay et al. further investigated the extract by bioassay-guided fractionation and two structurally related hirsutinolides displaying in vitro antiplasmodial activity $\left(\mathrm{IC}_{50} \sim 0.2 \mu \mathrm{g} \mathrm{mL} \mathrm{m}^{-1}\right.$ against $\left.\mathrm{D} 10\right)$ were isolated. These were $8 \alpha$-(2- methylacryloyloxy)-3-oxo-1-desoxy1,2-dehydrohirsutinolide-13-O-acetate (107), and $8 \alpha$ (5'-acetoxysenecioyloxy)-3-oxo-1-desoxy-1,2-dehydrohirsutinolide-13-O-acetate (108). These were found to be cytotoxic to mammalian Chinese hamster ovarian $(\mathrm{CHO})$ cells at similar concentrations, but proved to be attractive scaffolds for structure-activity relationship studies. Two main privileged substructures, a 2(5H)furanone unit and a dihydrofuran-4- one unit, were identified as potential pharmacophores, which may be responsible for the observed biological activity. Mucochloric and mucobromic acids were selected as appropriate $2(5 H)$-furanone substructures and these were shown to have comparable activity against the D10 and superior activity against the $\mathrm{K} 1$ strains relative to the hirsutinolide natural product. Mucochloric and mucobromic acids (109 and 110) also showed selective cytotoxicity to the malaria parasites compared to mammalian ( $\mathrm{CHO}$ ) cells in vitro. The antiplasmodial data obtained with respect to these two acids suggest that the 2 $(5 \mathrm{H})$ - furanone substructure is a key pharmacophore in the observed antiplasmodial activity. The identification of antiplasmodial hirsutinolides from $V$. staehelinoides suggests that they may play a role in the medicinal properties of the plant, but their potential for the development of anti-malarial drugs is limited due to inherent cytotoxicity and lack of selectivity. The results did however lead to the identification of potential pharmacophores, a $2(5 H)$-furanone unit and a dihydrofuran-4-one unit.

The benzophenone 2,5,2',6'-tetrahydroxybenzophenone (111), from the stem bark of Hypericum lanceolatum (Hypericaceae), exhibited an interesting activity against the multidrug-resistant strain W2mef, with an $\mathrm{IC}_{50}$ of $13.56 \mu \mathrm{g} \mathrm{mL}{ }^{-1}$ [90]. Ngouela et al. isolated guttiferone A 


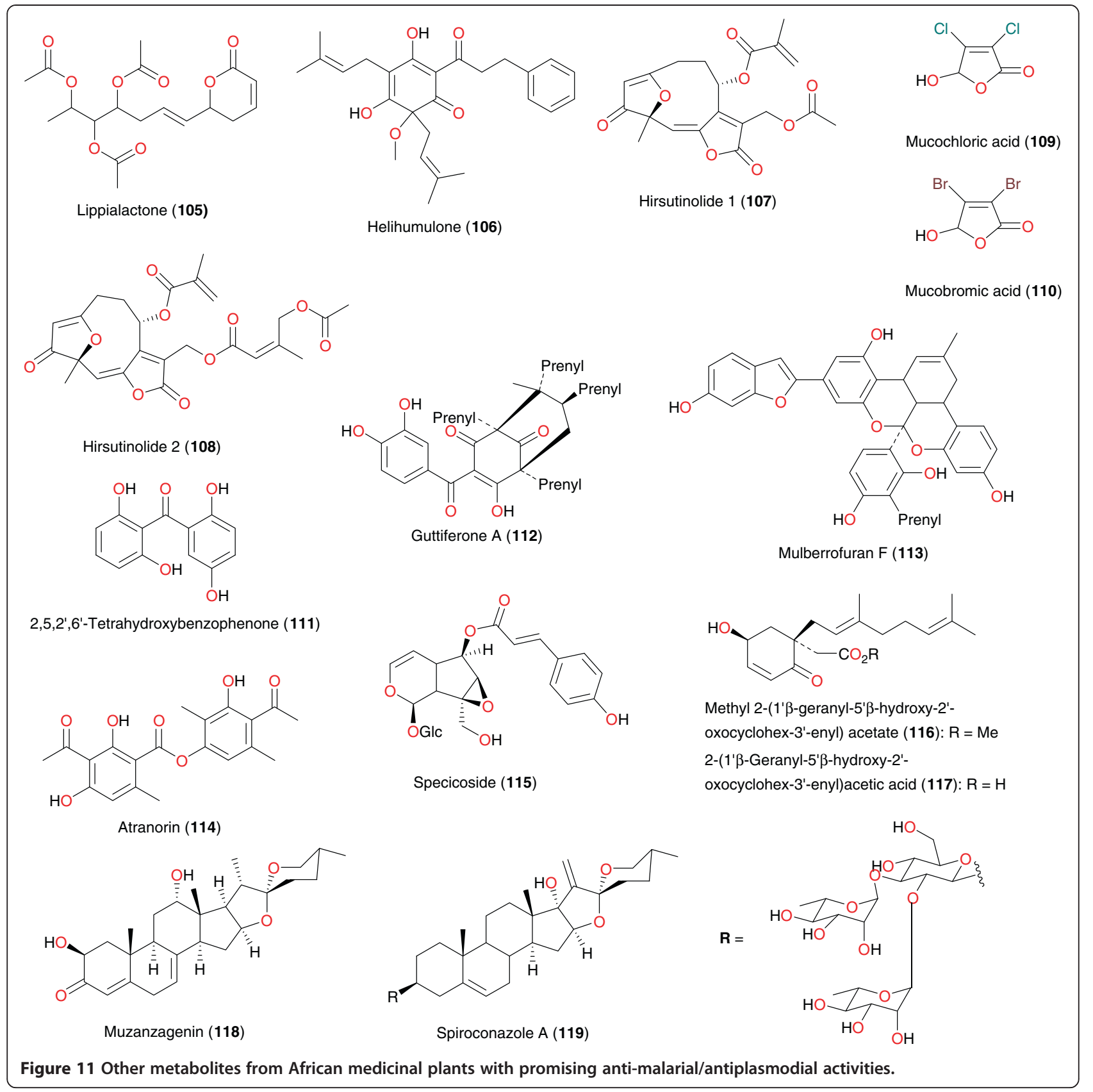

(112) from the seeds of Symphonia globulifera (Clusiaceae) [92]. This compound exhibited activity against the W2 Plasmodium sp. with $\mathrm{IC}_{50}$ of $3.17 \mu \mathrm{M}$. Mulberrofuran $\mathrm{F}$ (113), from the stem bark of Morus mesozygia (Moraceae), was active against FcB1-Columbia strain, considered to be resistant against chloroquine, with $\mathrm{IC}_{50}$ of $2.6 \mu \mathrm{g} \mathrm{mL} \mathrm{m}^{-1}$ [65]. Atranorin (114) and specicoside (115), derived from the stem bark extract of Kigelia africana (Bignoniaceae) [68,69], were both active against the multidrug-resistant W2mef strain of $P$. falciparum with respective $\mathrm{IC}_{50}$ values of $0.67 \mu \mathrm{g} \mathrm{mL} \mathrm{m}^{-1}$ and $0.52 \mu \mathrm{g} \mathrm{mL} \mathrm{m}^{-1}$.
The homogentisic acid derivatives methyl 2-(1' $\beta$-geranyl-5' $\beta$-hydroxy-2' - oxocyclohex-3'-enyl) acetate (116) and $2-(1$ ' $\beta$-geranyl-5' $\beta$-hydroxy- 2 ' - oxocyclohex- 3 'enyl) acetic acid (117) were isolated by Mbah et al. from the leaves of Glossocalyx brevipes (Monimiaceae) [102]. Compounds 116 and 117 exhibited both anti-malarial [102] and antisalmonellal activities [104]. The sapogenin muzanzagenin (118) and the saponin spiroconazole A (119), respectively isolated from Asparagus africanus (Asparagaceae) [97] and from the West Africa 'soap tree' Dracaena sp. (Dracaenaceae) [103], also demonstrated significant anti-malarial activities. Spiroconazole A is 
reported to exhibit pronounced antileishmanial, antimalarial and molluscicidal activities.

\section{Conclusions}

In this review, an attempt has been made to summarise the main finding of several research groups engaged in the search for naturally occurring active principles from African medicinal plants against P. falciparum. With multiple resistance developed by the malaria parasite, the cry has been towards obtaining new effective drugs. Attempts to develop 'green pharmacies' for improved phytomedicines against malaria are being encouraged by some NGOs and governments as part of their efforts to control malaria [105]. Additionally, modern hit/lead discovery efforts for specific anti-malarial drug targets are being encouraged. The trend has been towards accelerating this process by employing computer-based methods such as docking, virtual screening, pharmacophore modelling and binding-free energy calculations for hit/lead identification and combinatorial design of novel inhibitors against known anti-malarial drug targets. The practice of virtual screening is beginning to occupy the centre of drug discovery efforts [106] and it has been verified that developing NP libraries containing readily available compounds for screening virtual hits could be highly useful [107]. The authors of this paper have been developing NP databases containing three-dimensional structures of compounds derived from plants used in ATM [108-110] and using computed molecular descriptors to attempt to predict the pharmacokinetic profiles of NPs [110-112]. Since the role of NPs in drug discovery cannot be overemphasized [111-116], efforts are aimed at providing tools for research groups engaged in anti-malarial drug discovery, beginning with NPs derived from African medicinal plants. This is aimed at cutting down the cost of drug discovery when computational and 'wet lab' approaches are combined $[117,118]$. The intention is to make the current collection of threedimensional structures of naturally occurring antimalarials from African medicinal plants available for virtual screening. This shall be the scope of part III of this series.

\footnotetext{
Abbreviations

ADMET: Absorption, distribution, metabolism, excretion and toxicity;

ATM: African traditional medicine; DMPK: Drug metabolism and pharmacokinetics; FAS II: Fatty acid sytem II; NP: Natural product; WHO: World Health Organization; WM: Western medicine.
}

\section{Competing interests}

The authors declare that they have no competing interests.

\section{Authors' contributions}

FNK, LLL, JCN, and LMM conceived the idea. FNK, LLL and PAO participated in data collection. FNK and PAO contributed to data analysis, discussion of results and the conception of the paper under the supervision of LMM, WS, $L L L$, and JCN. FNK and PAO wrote the first draft of the paper and all authors agreed on the final version before submission.

\section{Acknowledgements}

Financial support is acknowledged from Lhasa Ltd, Leeds, UK through the Chemical and Bioactivity Information Centre (CBIC), University of Buea, Cameroon.

\section{Author details}

${ }^{1}$ Chemical and Bioactivity Information Centre, Department of Chemistry, Faculty of Science, University of Buea, PO Box 63, Buea, Cameroon. ${ }^{2}$ Department of Pharmaceutical Sciences, Martin-Luther University of Halle-Wittenberg, Wolfgang-Langenbeck Str. 4, 06120 Halle, Saale, Germany. ${ }^{3}$ Department of Chemistry, Faculty of Science, University of Douala, PO Box 24157, Douala, Cameroon.

Received: 31 October 2013 Accepted: 25 February 2014

Published: 6 March 2014

\section{References}

1. Nogueira CR, Lopes LMX: Antiplasmodial natural products. Molecules 2011, $16: 2146-2190$

2. White NJ: Antimalarial drug resistance. J Clin Invest 2004, 113:1084-1092.

3. WHO: World Malaria Report 2012. Geneva: World Health Organization; 2012. Available from http://who.int/malaria/publications/

world_malaria_report_2012/wmr2012_no_profiles.pdf (accessed on August 02, 2013).

4. Vogel G: Infectious disease - new map illustrates risk from the 'other' malaria. Science 2010, 329:618-618.

5. Addae-Mensah I, Fakorede F, Holtel A, Nwaka S: Traditional medicines as a mechanism for driving research innovation in Africa. Malar J 2011, 10(Suppl 1):S9.

6. Guantai E, Chibale K: How can natural products serve as a viable source of lead compounds for the development of new/novel anti-malarials? Malar J 2011, 10(Suppl 1):S2.

7. Cruz LR, Spangenberg T, Lacerda MVG, Wells TNC: Malaria in South America: a drug discovery perspective. Malar J 2013, 12:168.

8. Chin YW, Balunas MJ, Chai HB, Kinghorn AD: Drug discovery from natural sources. AAPS J 2006, 8:E239-E253.

9. Fabricant DS, Farnsworth NR: The value of plants used in traditional medicine for drug discovery. Environ Health Perspect 2001, 109:69-75

10. Ginsburg $H$, Deharo E: A call for using natural compounds in the development of new antimalarial treatments-an introduction. Malar $J$ 2011, 10(Suppl 1):S1.

11. Wells TNC: Natural products as starting points for future anti-malarial therapies: going back to our roots? Malar J 2011, 10(Suppl 1):S3.

12. Anthony MP, Burrows JN, Duparc S, JMoehrle J, Wells TNC: The global pipeline of new medicines for the control and elimination of malaria. Malar J 2012, 11:316.

13. Hostettmann K, Marston A, Ndjoko K, Wolfender JL: The potential of African plants as a source of drugs. Curr Org Chem 2000, 4:973-1010.

14. Efange SMN: Natural products: a continuing source of inspiration for the medicinal chemist. In Advances in Phytomedicine. Edited by Iwu MM, Wootton JC. Amsterdam: Elsevier Science; 2002:61-69.

15. Tona L, Ngimbi NP, Tsakala M, Mesia K, Cimanga K, Apers S, De Bruyne T, Pieters L, Totte J, Vlietinck AJ: Antimalarial activity of 20 crude extracts from nine African medicinal plants used in Kinshasa, Congo. J Ethnopharmacol 1999, 68:193-203.

16. Tona L, Cimanga RK, Mesia K, Musuamba CT, De Bruyne Apers TS, Hernans N, Van Miert S, Pieters L, Totté J, Vlietinck AJ: In vitro antiplasmodial activity of extracts and fractions from seven medicinal plants used in the Democratic Republic of Congo. J Ethnopharmacol 2004, 93:27-32.

17. Dike IP, Obembe OO, Adebiyi FE: Ethnobotanical survey for potential anti-malarial plants in south-western Nigeria. J Ethnopharmacol 2012, 144:618-626.

18. Gbadamosi IT, Moody JO, Lawal AM: Phytochemical screening and proximate analysis of eight ethnobotanicals used as antimalaria remedies in Ibadan, Nigeria. J Appl Biosci 2011, 44:2967-2971.

19. Adebayo JO, Krettli AU: Potential antimalarials from Nigerian plants: a review. J Ethnopharmacol 2011, 133:289-302.

20. De Silva A JR, De Ramos SA, Machado M, De Moura DF, Neto Z, Canto-Cavalheiro MM, Figueiredo P, Do Rosário VE, Amaral ACF, Lopes D: A review of antimalarial plants used in traditional medicine in communities in Portuguese-Speaking 
countries: Brazil, Mozambique, Cape Verde, Guinea-Bissau, São Tomé and Príncipe and Angola. Mem Inst Oswaldo Cruz 2011, 106(Suppl. I):142-158.

21. Ancolio C, Azas N, Mahiou V, Ollivier E, Di Giorgio C, Keita A, Timon-David P, Balansard G: Antimalarial activity of extracts and alkaloids isolated from six plants used in traditional medicine in Mali and Sao Tome. Phytother Res 2002, 16:646-649.

22. Puri M, Masum H, Heys J, Singer PA: Harnessing biodiversity: the Malagasy Institute of Applied Research (IMRA). BMC Int Health Hum Rights 2010, 10(Suppl 1):S9.

23. Rasoanaivo P, Ratsimamanga-Urverg S, Ramanitrahasimbola D, Rafatro H, Rakoto-Ratsimamanga A: Criblage d'extraits de plantes de Madagascar pour recherche d'activité antipaludique et d'effet potentialisateur de la chloroquine. J Ethnopharmacol 1999, 64:117-126.

24. Mbatchi SF, Mbatchi B, Banzouzi JT, Bansimba T, Nsonde Ntandou GF, Ouamba JM, Berry A, Benoit-Vical F: In vitro antiplasmodial activity of 18 plants used in Congo Brazzaville traditional medicine. J Ethnopharmacol 2006, 104:168-174.

25. Randrianarivelojosia M, Rasidimanana VT, Rabarison H, Cheplogoi PK, Ratsimbason M, Mulholland DA, Mauclère P: Plants traditionally prescribed to treat tazo (malaria) in the eastern region of Madagascar. Malar J 2003, 2:25.

26. Kumulungui BS, Ondo-Azi AS, Mintsa NA, Fumoux F, Traore A: In vitro antiplasmodial activity of seven plants commonly used against malaria in Burkina Faso. J Med Plant Res 2012, 6:2284-2288.

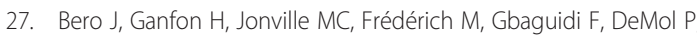
Moudachirou M, Quetin-Leclercq J: In vitro antiplasmodial activity of plants used in Benin in traditional medicine to treat malaria. J Ethnopharmacol 2009, 122:439-444.

28. Pillay P, Maharaj VJ, Smith PJ: Investigation South African plants as a source of antimalarial drugs. J Ethnopharmacol 2008, 129:438-454.

29. Soh PN, Benoit-Vical F: Are West African plants a source of future antimalarial drugs? J Ethnopharmacol 2007, 114:130-140.

30. Muthaura CN, Rukunga GM, Chhabra SC, Mungai GM, Njagi ENM: Traditional antimalarial phytotherapy remedies used by the Kwale community of the Kenyan Coast. J Ethnopharmacol 2007, 114:377-386.

31. Vonthron-Sénécheau C, Weniger B, Ouattara M, Bi FT, Kamenan A, Lobstein A, Brun R, Anton R: In vitro antiplasmodial activity and cytotoxicity of ethnobotanically selected Ivorian plants. J Ethnopharmacol 2003, 87:221-225.

32. Waako PJ, Katuura E, Smith P, Folb P: East African medicinal plants as a source of lead compounds for the development of new antimalarial drugs. Afr J Ecol 2007, 45(Suppl. 1):102-106.

33. Maregesi S, Van Miert S, Pannecouque C, Haddad MHF, Hermans N, Wright CW, Vlietinck AJ, Apers S, Pieters L: Screening of Tanzanian medicinal plants against Plasmodium falciparum and human immunodeficiency virus. Planta Med 2010, 76:195-201.

34. Ayuko TA, Njau RN, Cornelius W, Leah N, Ndiege IO: In vitro antiplasmodial activity and toxicity assessment of plant extracts used in traditional malaria therapy in the Lake Victoria Region. Mem Inst Oswaldo Cruz 2009, 104:689-694.

35. Weenen $H$, Nkunya MHH, Bray DH, Mwasumbi LB, Kinabo LS, Kilimali VAEB: Antimalarial activity of Tanzanian medicinal plants. Planta Med 1990, $56: 368-370$

36. Kuete $\mathrm{V}$, Efferth $\mathrm{T}$ : Cameroonian medicinal plants: pharmacology and derived natural products. Front Pharmacol 2010, 1:123.

37. Ntie-Kang F, Lifongo LL, Mbaze LM, Ekwelle N, Owono Owono LC, Megnassan E, Judson PN, Sippl W, Efange SMN: Cameroonian medicinal plants: a bioactivity versus ethnobotanical survey and chemotaxonomic classification. BMC Complement Altern Med 2013, 13:147.

38. Titanji VPK, Zofou D, Ngemenya MN: The antimalarial potential of medicinal plants used for the treatment of malaria in Cameroonian folk medicine. Afr J Trad CAM 2008, 5:302-321.

39. Magadula JJ, Erasto P: Bioactive natural products derived from the East African flora. Nat Prod Rep 2009, 26:1535-1554.

40. Zofou D, Ntie-Kang F, Sippl W, Efange SMN: Bioactive natural products derived from the Central African flora against neglected tropical diseases and HIV. Nat Prod Rep 2013, 30:1098-1120.

41. Bero J, Quetin-Leclercq J: Natural products published in 2009 from plants traditionally used to treat malaria. Planta Med 2011, 77:631-640.

42. Schwikkard S, van Heerden FR: Antimalarial activity of plant metabolites. Nat Prod Rep 2002, 19:675-692.
43. Bhatnagara S, Dasa P: Antimalarial activity in tropical plants: a review. J Herbs Spices Med Plants 2007, 13:103-132. doi:10.1300/J044v13n01_09.

44. Oliviera AB, Dolabela MF, Braga FC, Jacome RLRP, Varotti FP, Povoa MM: Plant-derived antimalarial agents: new leads and efficient phytomedicines: part I: alkaloids. Anias da Academia Brasiliera de Ciencias 2009, 81:715-740.

45. Batista R, Junior AJS, Oliviera AB: Plant-derived antimalarial agents: new leads and efficient phytomedicines: part II: non-alkaloidal natural products. Molecules 2009, 14:3037-3072.

46. Saxena S, Pant N, Jain DC, Bhakuni RS: Antimalarial agents from plant sources. Curr Sci 2003, 85:1314-1329.

47. Bero J, Frédérich M, Quetin-Leclercq J: Antimalarial compounds isolated from plants used in traditional medicine. J Pharm Pharmacol 2009, 61:1401-1433.

48. Frédérich $M$, Tits $M$, Angenot $L$ : Potential antimalarial activity of indole alkaloids. Trans R Soc Trop Med Hyg 2008, 102:11-19.

49. Amoa Onguéné $P$, Ntie-Kang F, Lifongo LL, Ndom JC, Sippl W, Mbaze LM: The potential of anti-malarial compounds derived from African medicinal plants, part I: a pharmacological evaluation of alkaloids and terpenoids. Malar J 2013, 12:449.

50. Mahmoudi N, de Julian-Ortiz JV, Cicerone L, Galvez J, Mazier D, Danism M, Derouin F, Garcia-Domenech R: Identification of new antimalarial drugs by linear discriminant analysis and topological virtual screening. J Antimicrob Chemother 2006, 57:489-497.

51. Willcox M, Bodeker G, Rasanaivo P: Traditional Medicinal Plants and Malaria Paris: CRC Press; 2004.

52. Rasoanaivo P, Oketch-Rabah H: Preclinical considerations on anti-malarial phytomedicines: Part II, Efficacy evaluation. Antananarivo: Inst., Malgache de Recherches Appliquées; 1998.

53. Freundlich JS, Anderson JW, Sarantakis D, Shieh HM, Yu M, Valderramos JC, Lucumi E, Kuo M, Jacobs WR Jr, Fidock DA, Schiehser GA, Jacobus DP, Sacchettini JC: Synthesis, biological activity, and X-ray crystal structural analysis of diaryl ether inhibitors of malarial enoyl acyl carrier protein reductase: part 1: 4'-substituted triclosan derivatives. Bioorg Med Chem Lett 2005, 15:5247-5252.

54. Perozzo R, Kuo M, Sidhu ABS, Valiyaveettil JT, Bittman R, Jacobs WR Jr, Fidock DA, Sacchettini JC: Structural elucidation of the specificity of the antibacterial agent triclosan for malarial enoyl acyl carrier protein reductase. Biol Chem 2002, 277:13106-13114.

55. Elford BC: L-Glutamine influx in malaria-infected erythrocytes: a target for antimalarials? Parasitol Today 1986, 2:309-312

56. Yenesew A, Derese S, Irungu B, Midiwo JO, Waters NC, Liyala P, Akala H, Heydenreich M, Peter MG: Flavonoids and isoflavonoids with antiplasmodial activities from the root bark of Erythrina abyssinica. Planta Med 2003, 69:658-661.

57. Yenesew A, Induli M, Derese S, Midiwo JO, Heydenreich M, Peter MG, Akala H, Wangui J, Liyala P, Waters NC: Anti-plasmodial flavonoids from the stem bark of Erythrina abyssinica. Phytochemistry 2004, 65:3029-3032.

58. Yenesew A, Derese S, Midiwo JO, Oketch-Rabah HA, Lisgarten J, Palmer R, Heydenreich M, Peter MG, Akala H, Wangui J, Liyala P, Waters NC: Anti-plasmodial activities and X-ray crystal structures of rotenoids from Millettia usaramensis subspecies usaramensis. Phytochemistry 2003, 64:773-779.

59. Nkunya MH, Weenen $H$, Bray DH, Mgani QA, Mwasumbi LB: Antimalarial activity of Tanzanian plants and their active constituents: the genus Uvaria1. Planta Med 1991, 57:341-343.

60. Joseph CC, Magadula JJ, Nkunya MHH: A novel antiplasmodial 3',5'diformylchalcone and other constituents of Friesodielsia obovata. Nat Prod Res 2007, 21:1009-1015.

61. Midiwo JO, Omoto FM, Yenesew A, Akala HM, Wangui J, Liyala P, Wasunna C, Waters NC: The first 9-hydroxyhomoisoflavanone, and antiplasmodial chalcones, from the aerial exudates of Polygonum senegalense. Arkivoc 2007, 9:21-27.

62. Makangara J, Jonker S, Nkunya M: A novel phenanthrenolide and C-benzyl dihydrochalcones from Uvaria puguensis. Nat Prod Lett 2010, 16:267-272.

63. Ngameni B, Watchueng J, Boyom FF, Keumedjio F, Ngadjui BT, Gut J, Abegaz BM, Rosenthal PJ: Antimalarial prenylated chalcones from the twigs of Dorstenia barteri var. subtriangularis. Arkivoc 2007, 13:116-123.

64. Yenesew A, Twinomuhwezi H, Kabaru JM, Akala HM, Kiremire BT, Heydenreich M, Peter MG, Eyase FL, Waters NC, Walsh DS: Antiplasmodial and larvicidal flavonoids from Derris trifoliata. Bull Chem Soc Ethiop 2009, 23:409-414. 
65. Zelefack F, Guilet D, Valentin A, Fongang RCS, Kom B, Chevalley S, Ngouela SA, Tsamo E, Fabre N, Dijoux-Franca MG: Antiplasmodial and cytotoxic activities of flavonoids and arylbenzofuran derivatives from Morus mesozygia. Greener J Biol Sci 2012, 2:020-024.

66. Bankeu JJK, Khayala R, Lenta BN, Noungoué DT, Ngouela SA, Mustafa SA, Asaad K, Choudhary MI, Prigge ST, Hasanov R, Nkengfack AE, Tsamo E, Ali MS: Isoflavone dimers and other bioactive constituents from the figs of Ficus mucuso. J Nat Prod 2011, 74:1370-1378.

67. Andayi AW, Yenesew A, Derese S, Midiwo JO, Gitu PM, Jondiko OJ, Akala H, Liyala P, Wangui J, Waters NC, Heydenreich M, Peter MG: Antiplasmodial flavonoids from Erythrina sacleuxii. Planta Med 2006, 72:187-189.

68. Zofou D, Kengne AB, Tene M, Ngemenya MN, Tane P, Titanji VPK: In vitro antiplasmodial activity and cytotoxicity of crude extracts and compounds from the stem bark of Kigelia africana (Lam.) Benth (Bignoniaceae). Parasitol Res 2011, 108:1383-1390.

69. Zofou D, Tene M, Tane P, Titanji VPK: Antimalarial drug interactions of compounds isolated from Kigelia africana (Bignoniaceae) and their synergism with artemether, against the multidrug-resistant W2mef Plasmodium falciparum strain. Parasitol Res 2012, 110:539-544.

70. Boyom FF, Madiesse EK, Bankeu JJ, Tsouh VP, Lenta BN, Mbacham WF, Tsamo E, Zollo PHA, Gut J, Rosenthal PJ: Falcipain 2 inhibitors and antiplasmodial compounds from a bio-guided fractionation of the fruits of Sorindeia juglandifolia A. Rich. (Anacardiaceae) growing in Cameroon. Malar J 2010, 9(Suppl 2):P6.

71. Kamkumo RG, Ngoutane AM, Tchokouaha LRY, Fokou PVT, Madiesse EAK, Legac J, Kezetas JB, Lenta BN, Boyom FF, Dimo T, Mbacham WF, Gut J, Rosenthal PJ: Compounds from Sorindeia juglandifolia (Anacardiaceae) exhibit potent antiplasmodial activities in vitro and in vivo. Malar J 2012, 11:382-389.

72. Asres K, Bucar F, Knauder E, Yardley V, Kendrick H, Croft SL: In vitro antiprotozoal activity of extract and compounds from the stem bark of Combretum molle. Phytother Res 2001, 15:613-617.

73. Banzouzi JT, Prado R, Menan H, Valentin A, Roumestan C, Mallie M, Pelissier $Y$, Blache Y: In vitro antiplasmodial activity of extracts of Alchornea cordifolia and identification of an active constituent: ellagic acid. J Ethnopharmacol 2002, 81:399-401.

74. Cheplogoi PK, Mulholland DA, Coombes PH, Randrianarivelojosia M: An azole, an amide and a limonoid from Vepris uguenensis (Rutaceae). Phytochemistry 2008, 69:1384-1388.

75. Lannang AM, Louh GN, Lontsi D, Specht S, Sarite SR, Flörke U, Hussain H Hoerauf A, Krohn K: Antimalarial compounds from the root bark of Garcinia polyantha Olv. J Antibiot 2008, 61:518-523.

76. Deck LM, Royer RE, Chamblee BB, Hernandez VM, Malone RR, Torres JE, Hunsaker LA, Piper RC, Makler MT, Vander Jagt DL: Selective inhibitors of human lactate dehydrogenases and lactate dehydrogenase from the malarial parasite Plasmodium falciparum. J Med Chem 1998, 41:3879-3887.

77. Senn M, Gunzenhauser S, Brun R, Sequin U: Antiprotozoal polyacetylenes from the Tanzanian medicinal plant Cussonia zimmermannii. J Nat Prod 2007, 70:1565-1569.

78. Achenbach $\mathrm{H}$, Waibel $\mathrm{R}$, Nkunya MHH, Weenen $\mathrm{H}$ : Antimalarial compounds from Hoslundia opposite. Phytochemistry 1992, 31:3781-3784.

79. Ajaiyeoba EO, Ashidi JS, Okpako LC, Houghton PJ, Wright CW Antiplasmodial compounds from Cassia siamea stem bark extract. Phytother Res 2008, 22:254-255.

80. Lenta BN, Devkota PK, Ngouela S, Boyom FF, Naz Q, Choudhary MI, Tsamo E, Rosenthal PJ, Sewald N: Anti-plasmodial and cholinesterase inhibiting activities of some constituents of Psorospermum glaberrimum. Chem Pharm Bull 2008, 56:222-226.

81. Lenta BN, Ngouela S, Boyom FF, Tantangmo F, Tchouya GRF, Tsamo E, Gut J, Rosenthal PJ, Connolly JD: Anti-plasmodial activity of some constituents of the root bark of Harungana madagascariensis LAM. (Hypericaceae). Chem Pharm Bull 2007, 55:464-467.

82. Makinde JM, Amusan OOG, Adesogan EK: The antimalarial activity of Spathodea campanulata stem bark extract on Plasmodium berghei berghei in mice. Planta Med 1988, 54:122-125

83. Dagne E, Steglich W: Knipholone: a unique anthraquinone derivative from Kniphofia foliosa. Phytochemistry 1984, 23:1729-1731.

84. Bringmann G, Menche D, Bezabih M, Abegaz BM, Kaminsky R: Antiplasmodial activity of knipholone and related natural phenylanthraquinones. Planta Med 1999, 65:757-758.

85. Weiss CR, Moideen SVK, Croft SL, Houghton PJ: Activity of extracts and isolated naphthoquinones from Kigelia pinnata against Plasmodium falciparum. J Nat Prod 2000, 63:1306-1309.
86. Cubukcu B, Bray DH, Warhurst DC, Mericli AH, Ozhatay N, Sariyar G: In vitro antimalarial activity of crude extracts and compounds from Artemisia abrotanum L. Phytother Res 1990, 4:203-204.

87. Noster S, Kraus L: In vitro antimalarial activity of Coutarea latiflora and Exostema caribaeum extracts on Plasmodium falciparum. Planta Med 1990, 56:63-65.

88. Oketch-Rabah HA, Mwangi JW, Lisgarten J, Mberu EK: A new antiplasmodial coumarin from Toddalia asiatica roots. Fitoterapia 2000, 71:636-640.

89. Mthembu XS: A phytochemical study of Schefflera umbellfera and Elephantorrhiza elephantIna. MSc thesis. Pietermaritzburg, South Africa: School of Chemistry, University of KwaZulu-Natal; 2007.

90. Zofou D, Kowa TK, Wabo HK, Ngemenya MN, Tane P, Titanji VPK: Hypericum lanceolatum (Hypericaceae) as a potential source of new anti-malarial agents: a bioassay-guided fractionation of the stem bark. Malar J 2011, 10:167.

91. Azebaze AGB, Meyer M, Valentin A, Nguemfo EL, Fomum ZT, Nkengfack AE: Prenylated xanthone derivatives with antiplasmodial activity from Allanblackia monticola STANER L.C. Chem Pharm Bull 2006, 54:111-113.

92. Ngouela S, Lenta BN, Noungoue DT, Ngoupayo J, Boyom FF, Tsamo E, Gut J, Rosenthal PJ, Connolly JD: Anti-plasmodial and antioxidant activities of constituents of the seed shells of Symphonia globulifera Linn $\mathrm{f}$. Phytochemistry 2006, 67:302-306.

93. Lenta BN, Kamdem LM, Ngouela S, Tantangmo F, Devkota KP, Boyom FF Rosenthal PJ, Tsamo E: Antiplasmodial constituents from the fruit pericarp of Pentadesma butyracea. Planta Med 2011, 77:377-379.

94. Kuria KAM, Chepkwony H, Govaerts C, Roets E, Busson R, de Witte P, Zupko I, Hoornaert G, Quiryren L, Maes L, Janssens L, Hoogmartens J, Laekeman G: The antiplasmodial activity of isolates from Ajuga remota. J Nat Prod 2002, 65:789-793.

95. Ohigashi H, Hoffman MA, Izutsu D, Koshimizu K, Kawanaka M, Sugiyama H, Kirby GC, Warhurst DC, Allen D, Wright CW, Phillipson JD, Timon-David P, Delmas F, Elias R, Balansard G: Toward the chemical ecology of medicinal plant use in chimpanzees: the case of Vernonia amygdalina, a plant used by wild chimpanzees possibly for parasite-related diseases. $J$ Chem Ecol 1994, 20:541-553.

96. Ramalhete C, Abrantes M, Mil-Homens T, Duarte N, Lopes D, Cravo P, Madureira MC, Ascenso J, Ferreira MJU: Search for antimalarial compounds from Pycnanthus angolensis. Planta Med 2007, 73:P160.

97. Oketch-Rabah HA, Dossaji SF, Christensen SB, Frydenvang K, Lemmich E: Antiprotozoal compounds from Asparagus africanus. J Nat Prod 1997, 60:1017-1022.

98. Ludere MT, Van Teunis Ree T, Robert Vleggaar R: Isolation and relative stereochemistry of lippialactone, a new antimalarial compound Ifrom Lippia javanica. Fitoterapia 2013, 86:188-192.

99. Jakupovic J, Zdero C, Grenz M, Tsichritzis F, Lehmann L, Hashemi-Nejad SM, Bohlmann F: Twenty-one acylphloroglucinol and further constituents from South African Helichrysum species. Phytochemistry 1989, 28:1119-1131.

100. Van Vuuren SF, Viljoen AM, Van Zyl RL, Van Heerden FR, Baser KHC: The antimicrobial and toxicity profiles of helihumulone, leaf essential oil and extracts of Helichrysum cymosum (L.) D. Don subsp. cymosum. S Afr J Bot 2006, 72:287-290.

101. Pillay P, Vleggaar R, Maharaj VJ, Smith PJ, Lategan CA, Chouteau F, Chibale K: Antiplasmodial hirsutinolides from Vernonia staehelinoides and their utilization towards a simplified pharmacophore. Phytochemistry 2007, 68(8):1200-1205.

102. Mbah JA, Tane P, Ngadjui BT, Connolly JD, Okunji CC, Iwu MM, Schuster BM: Antiplasmodial agents from the leaves of Glossocalyx brevipes. Planta Med 2004, 70:437-440.

103. Okunji CO, Iwu MM, Jackson JE, Tally JD: Biological activity of saponins from two Dracaena species. Adv Exp Med Biol 1996, 404:415-428.

104. Gatsing D, Mbah JA, Garba IH, Tane P, Djemgou P, Njih-Nkah B: An antisalmonellal agent from the leaves of Glossocalyx brevipes Benth (Monimiaceae). Pak J Biol Sci 2006, 9:84-87.

105. Willcox M: Improved traditional phytomedicines in current use for the clinical treatment of malaria. Planta Med 2011, 77:662-671.

106. Klebe G: Virtual ligand screening: strategies, perspectives and limitations. Drug Discov Today 2006, 11:580-594.

107. Quinn RJ, Carroll AR, Pham MB, Baron P, Palframan ME, Suraweera L, Pierens GK, Muresan S: Developing a drug-like natural product library. J Nat Prod 2008, 71:464-468. 
108. Ntie-Kang F, Mbah JA, Mbaze LM, Lifongo LL, Scharfe M, Ngo Hanna J, Cho-Ngwa F, Onguéné PA, Owono LCO, Megnassan E, Sippl W, Efange SMN: CamMedNP: building the Cameroonian 3D structural natural products database for virtual screening. BMC Complement Altern Med 2013, 13:88.

109. Ntie-Kang F, Onquéné PA, Scharfe M, Owono LCO, Megnassan E, Mbaze LM, Sippl W, Efange SMN: ConMedNP: a natural product library from Central African medicinal plants for drug discovery. RSC Adv 2014, 4:409-419.

110. Ntie-Kang F, Zofou D, Babiaka SB, Meudom R, Scharfe M, Lifongo LL, Mbah JA, Mbaze LM, Sippl W, Efange SMN: AfroDb: a select highly potent and diverse natural product library from African medicinal plants. PLOS ONE 2013, 8:e78085.

111. Ntie-Kang F, Mbah JA, Lifongo LL, Owono LCO, Megnassan E, Mbaze LM, Judson PN, Sippl W, Efange SMN: Assessing the pharmacokinetic profile of the CamMedNP natural products database: an in silico approach. Org Med Chem Lett 2013, 3:10.

112. Ntie-Kang F, Lifongo LL, Mbah JA, Owono LCO, Megnassan E, Mbaze LM Judson PN, Sippl W, Efange SMN: In silico drug metabolism and pharmacokinetic profiles of natural products from medicinal plants in the Congo basin. In Silico Pharmacol 2013, 1:12.

113. Koehn FE, Carter GT: The evolving role of natural products in drug discovery. Nat Rev Drug Discov 2005, 4:206-220.

114. Harvey AL: Natural products in drug discovery. Drug Discov Today 2008 13:894-901.

115. Newman DJ: Natural products as leads to potential drugs: an old process or the new hope for drug discovery? J Med Chem 2008, 51:2589-2599.

116. Li JWH, Vederas JC: Drug discovery and natural products: end of an era or an endless frontier? Science 2009, 325:161-165.

117. Lipinski CA, Lombardo F, Dominy BW, Feeney PJ: Experimental and computational approaches to estimate solubility and permeability in drug discovery and development settings. Adv Drug Delivery Rev 1997, 23:3-25.

118. DiMasi JA, Hansen RW, Grabowsk HG: The price of innovation: new estimates of drug development costs. J Health Econ 2003, 22:151-185.

doi:10.1186/1475-2875-13-81

Cite this article as: Ntie-Kang et al:: The potential of anti-malarial compounds derived from African medicinal plants, part II: a pharmacological evaluation of non-alkaloids and non-terpenoids. Malaria Journal 2014 13:81.

\section{Submit your next manuscript to BioMed Central and take full advantage of:}

- Convenient online submission

- Thorough peer review

- No space constraints or color figure charges

- Immediate publication on acceptance

- Inclusion in PubMed, CAS, Scopus and Google Scholar

- Research which is freely available for redistribution

Submit your manuscript at www.biomedcentral.com/submit 